\title{
TOWARD QUANTIFYING THE INCREASING ROLE OF OCEANIC HEAT IN SEA ICE LOSS IN THE NEW ARCTIC
}

by E. Carmack, I. Polyakov, L. Padman, I. Fer, E. Hunke, J. Hutchings, J. Jackson, D. Kelley, R. Kwok, C. Layton, H. Melling, D. Perovich, O. Persson, B. Ruddick, M.-L. Timmermans, J. Toole, T. Ross, S. Vavrus, and P. Winsor

\section{Small changes in the ways that the ocean transports heat to the overlying ice cover could have a substantial effect on future changes in Arctic ice cover.}

It was the best of ice, it was the worst of ice, It was the age of growth, it was the age of melt, It was the season of multiyear, it was the season of first year, We had thick ice before us, we had no ice before us.

$\mathrm{T}$ his paraphrasing, by Don Perovich, of Charles Dickens's A Tale of Two Cities describes the startling changes in Arctic sea ice that have taken place in the last two decades (Fig. 1); indeed, the declines in Arctic sea ice area, thickness, and volume have emerged as the best-known signatures of global climate change. The Arctic has, as Jeffries et al. (2013) noted, entered a "new normal" state, with multiple impacts on oceanic, atmospheric, and terrestrial systems (Bhatt et al. 2014). Ice loss is expected to continue (Overland and Wang 2013), with implications for governance, economics, security, and Northern Hemisphere weather (Jeffries et al. 2013).
AFFILIATIONS: CARMACK-Fisheries and Oceans Canada, Sidney, British Columbia, Canada, and College of Natural Science and Mathematics, University of Alaska Fairbanks, Fairbanks, Alaska; PolYAKOV-International Arctic Research Center, and College of Natural Science and Mathematics, University of Alaska Fairbanks, Fairbanks, Alaska; PADMAN-Earth and Space Research, Corvallis, Oregon; FER-Geophysical Institute, University of Bergen and Bjerknes Centre for Climate Research, Bergen, Norway; HUNKe-Los Alamos National Laboratory, Los Alamos, New Mexico; Hutchings-Oregon State University, Corvallis, Oregon; JACKSON-Hakai Institute, Heriot Bay, British Columbia, Canada; Kelley, Layton, Ruddick, And Ross-Dalhousie University, Halifax, Nova Scotia, Canada; Kwok-Jet Propulsion Laboratory, California Institute of Technology, Pasadena, California; MelLing-Fisheries and Oceans Canada, Sidney, British Columbia, Canada; PerovicHCold Regions Research and Engineering Laboratory, Hanover,
New Hampshire; Persson-Cooperative Institute for Research in Environmental Sciences, University of Colorado Boulder, Boulder, Colorado; Timmermans-Yale University, New Haven, Connecticut; TOole-Woods Hole Oceanographic Institution, Woods Hole, Massachusetts; VAVRUS-Center for Climatic Research, University of Wisconsin-Madison, Madison, Wisconsin; Winsor-Institute of Marine Science, University of Alaska Fairbanks, Fairbanks, Alaska CORRESPONDING AUTHOR: Igor Polyakov, IARC, UAF, P.O. Box 757335, Fairbanks, AK 99775

E-mail: igor@iarc.uaf.edu

The abstract for this article can be found in this issue, following the table of contents.

DOI:10.II75/BAMS-D-13-00177.I

In final form 14 January 2015

(C)2015 American Meteorological Society 
The causes of this ice loss are complex, involving changes in atmospheric and oceanic heat, freshwater and momentum fluxes, and internal feedbacks that result from the sensitivity of the Arctic atmosphereice-ocean system to phase changes in ice and snow cover (Serreze and Barry 2011; Stroeve et al. 2012; Wassmann and Lenton 2012). The consequences of sea ice loss are potentially far reaching: ice cover anomalies affect atmospheric circulation patterns locally, probably remotely (Honda et al. 1996; Grassi et al. 2013), and possibly even exert a significant influence on midlatitude weather patterns, although the evidence for this is still equivocal (Liu et al. 2012; Francis and Vavrus 2012; Barnes 2013; Screen and Simmonds 2013; Mori et al. 2014; Cassano et al. 2014).

As ice volume declines, we expect stronger seasonal cycling of heat content in the upper ocean and exchanges with the atmosphere and ice (e.g., Tietsche et al. 2011) and the potential for increased annualaveraged ocean-ice heat exchange. The contribution of ocean heat flux to the mass budget of Arctic sea ice was recognized over 40 years ago by Maykut and Untersteiner (1971). Based on analyses of data from the drift of Ice Station Alpha in 1957/58 and of their one-dimensional thermodynamic model of sea ice, these authors estimated that maintaining the annually averaged Arctic ice cover typical of the mid-twentieth century required a basin-averaged flux of heat from the ocean to the ice of $1-3 \mathrm{~W} \mathrm{~m}^{-2}$. This value is of comparable magnitude to the estimated heat-flux convergence related to inflows from the Pacific and Atlantic Oceans through the Bering and Fram Straits, respectively (Pnyushkov et al. 2015; Shimada et al. 2006; Woodgate et al. 2012). These results suggest that small changes in the ways that the ocean transports heat originating from the seasonal cycle of surface fluxes, plus advective inputs from the sub-Arctic oceans and rivers, could have a significant effect on current and future changes in Arctic ice cover. However, the inferred annual-averaged net fluxes are orders of magnitude less than the seasonal and shorter-term fluxes from the atmosphere and ocean to the ice.

Confirming the ocean's role in the evolution of the Arctic ice pack is difficult given the typically short Arctic field programs. While a significant volume of Arctic sea ice is lost to outflow at the Fram Strait every year (Kwok 2009), there seems to be no observable trend in the 28-yr record (1982-2009) in ice export (Spreen et al. 2011; Kwok et al. 2013). In the backdrop of a warming trend, however, the decline in ice thickness could be triggered by large export events (Kwok and Rothrock 1999), with associated enhanced transpolar drift creating a younger ice pack more vulnerable to summer melt (Rigor and Wallace 2004; Nghiem et al. 2007; Hutchings and Rigor 2012). Kwok and Cunningham (2010) found that the melt of thick multiyear ice (MYI) advected into the summer Beaufort Sea, especially after 2000, has contributed directly to the depletion of Arctic MYI coverage and volume. Lukovich and Barber (2006) noted that the reversal of the Beaufort Gyre by increased cyclogenesis over the Canada Basin has increased in frequency since 1990, affecting both sea ice extent and dynamics. Thus, variations in circulation patterns and momentum transfer to the ice must also be considered when assessing changes in total Arctic ice volume.

With these research challenges in mind, a workshop was convened in Fairbanks, Alaska, in March 2013 to identify ways to improve our ability to measure and model the heat and mass budgets of Arctic sea ice. The "Untersteiner Workshop: On the Role and Consequences of Ocean Heat Flux in Sea Ice Melt" (www.iarc.uaf.edu/en/workshops/20I3 /untersteiner) honored the immeasurable contributions to polar science by Norbert Untersteiner, who passed away in March 2012. This paper summarizes

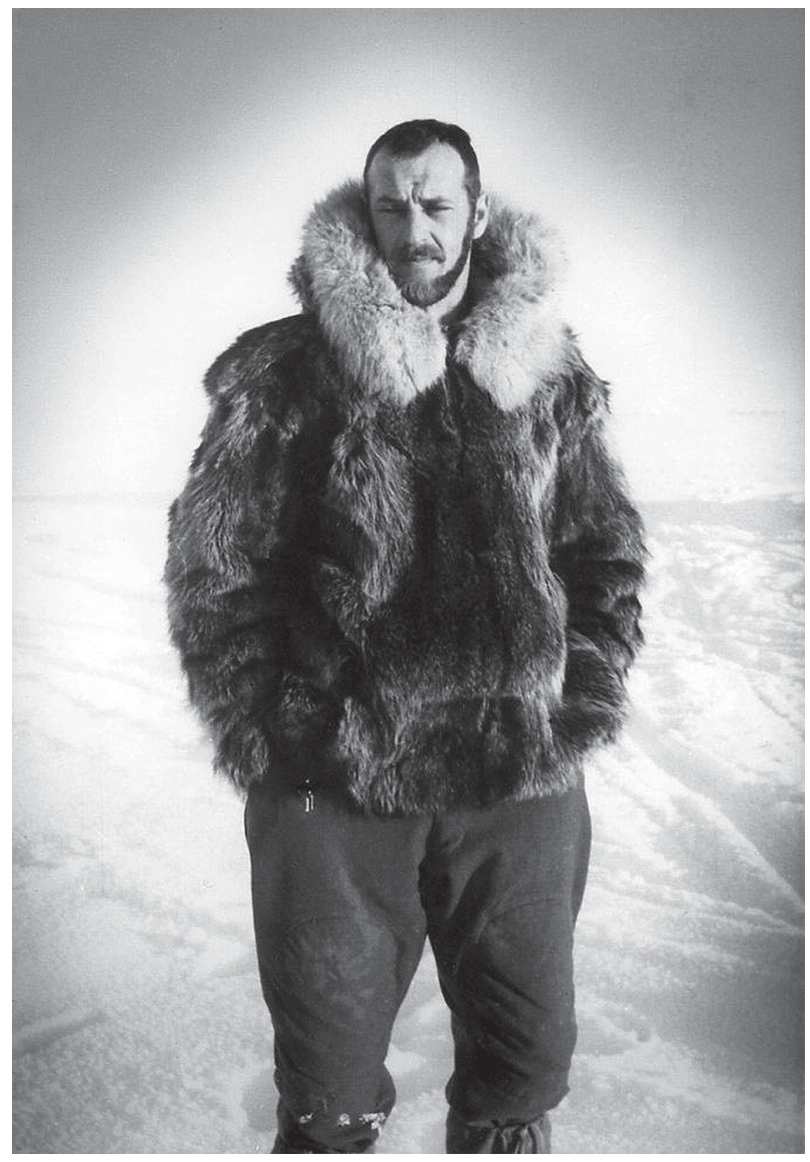

Norbert Untersteiner (1926-2012) 
the outcomes of this workshop and recommends an integrated course of research that will provide better understanding of the role of changing Arctic Ocean forcing and feedback mechanisms on the Arctic ice pack. For additional perspectives on Arctic change, see Jeffries et al. (2013), Barber et al. (2012), Vaughan et al. (2013), Straneo et al. (2013), Bhatt et al. (2014), and Vihma et al. (2014) for recent reviews of Arctic sea ice, atmospheric variability, Greenland land-ice-ocean interactions, marine ecosystems, impacts on other elements of the Earth system, and small-scale physical processes in the marine Arctic climate system, respectively.

FIG. I. Summary of linear decadal trends (red lines) and pattern of changes in the following: (a) Anomalies in Arctic sea ice extent from satellite passive microwave observations [based on procedures in Comiso and Nishio (2008)]. Uncertainties are discussed in the text. (b) Multiyear sea ice coverage on I Jan from analysis of the Quick Scatterometer (QuikSCAT) time series (Kwok 2009); gray band shows uncertainty in the retrieval. (c) Sea ice thickness from submarine (blue), satellites (black) (Kwok and Rothrock 2009), and in situ/electromagnetic (EM) surveys (circles) (Haas et al. 2008); trend in submarine ice thickness is from multiple regression of available observations within the data release area (Rothrock et al. 2008). Error bars show uncertainties in observations. (d) Anomalies in buoy (Rampal et al. 2009) and satellite-derived sea ice drift speed (Spreen et al. 20II). (e) Length of melt season [updated from Markus et al. (2009)]; gray band shows the basinwide variability. From Vaughan et al. (20l3).
OBSERVATIONS OF ARCTIC SEA ICE CHANGE. Characteristics of the Arctic ice pack include extent and area, thickness and volume, snow cover, and motion. Recent dramatic changes in these properties (Fig. 1) have been documented with a variety of in situ and remote sensing techniques. a) Annual ice extent

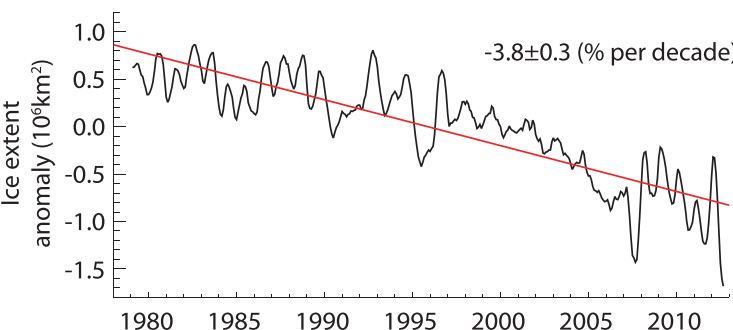

b) Multiyear ice coverage (Jan-1)

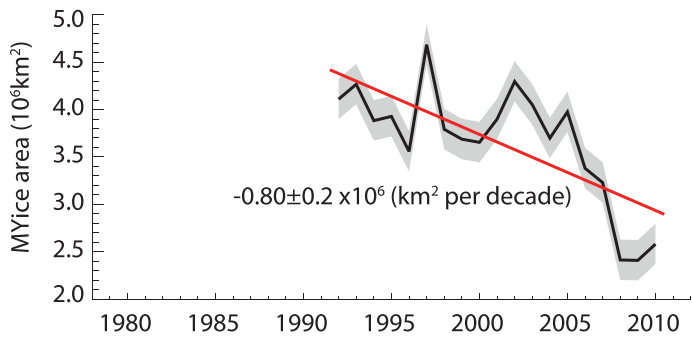

c) Ice thickness

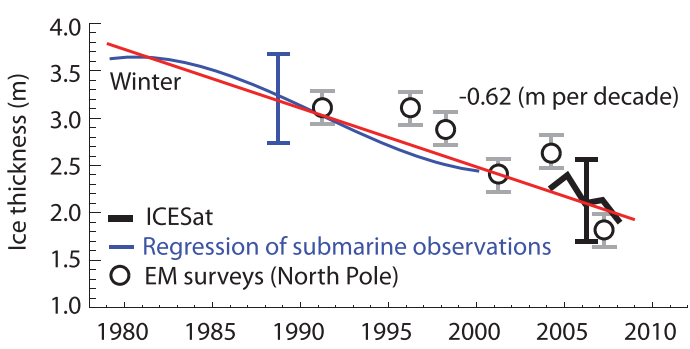

d) Sea ice drift speed

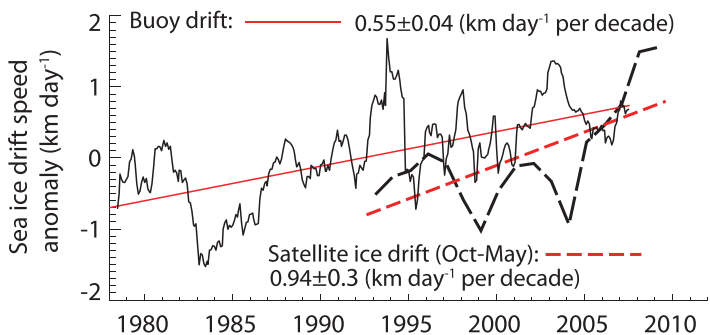

e) Average length of melt season

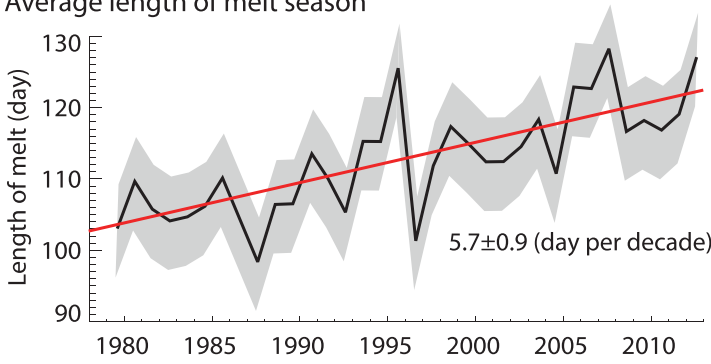

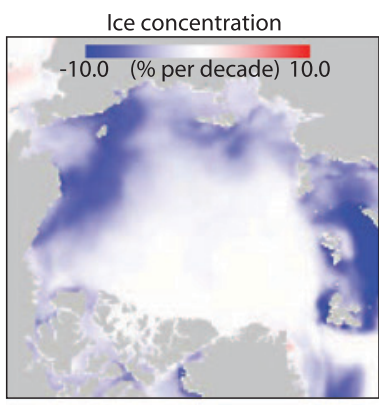

Multiyear ice concentration

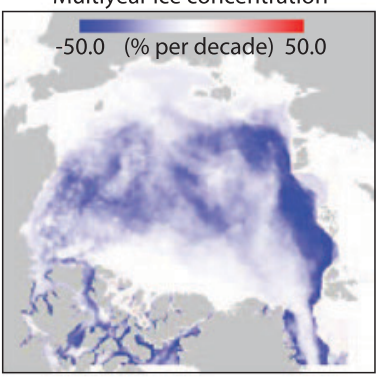

Thickness

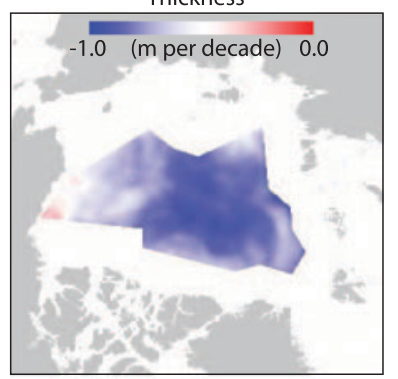

Drift speed

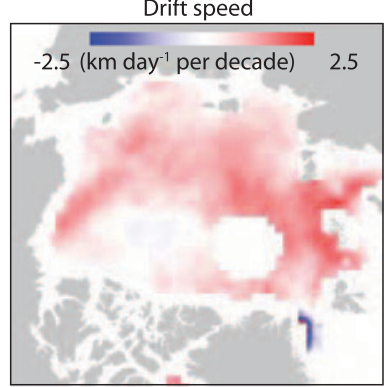

Length of melt season

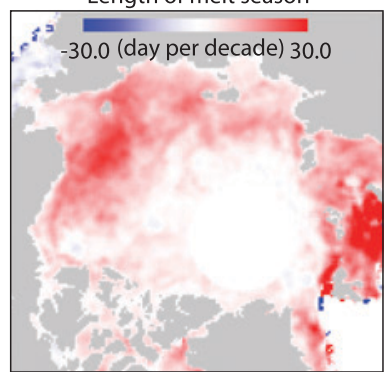


When viewing such one-dimensional time series, however, it is important to take into account the varieties of ice and snow across the Arctic domain, the differences in forcing of shelf and deep basin regions, the distinctive inputs of heat from adjacent oceans and rivers, and the multiple and interacting processes that act to transport heat both laterally and vertically beneath the ice. This system is shown schematically in Fig. 2 and is discussed below.

Ice extent and area. The global distribution of ice concentration has been mapped at approximately $25-\mathrm{km}$ resolution every 1-2 days since 1979 using satellite-based multichannel passive microwave sensing (e.g., Comiso 2012; Parkinson and Cavalieri 2008; Stammerjohn et al. 2012). In these analyses, sea ice extent is defined as the sum of ice-covered areas with concentrations of $15 \%$ or greater, and sea ice area is the summed product of the ice concentration and its area for each element within the ice extent. From the monthly anomaly data with November 1978-December 2012 as the baseline for the anomalies, the overall trend in Arctic ice extent for 1979-present is $-3.8 \%$ decade $^{-1}$ (Fig. 1a); however, for September only (containing the annual ice extent minimum) and extending the record to September 2014, the rate is $13.1 \%$ decade $^{-1}$ (Vaughan et al. 2013). The perennial ice cover (ice that has survived at least one summer) decreased from $7.9 \times 10^{6} \mathrm{~km}^{2}$ in 1980 to just $3.5 \times 10^{6} \mathrm{~km}^{2}$ in 2012 , while the multiyear extent decreased from $6.2 \times 10^{6} \mathrm{~km}^{2}$ in 1980 to about $2.5 \times 10^{6} \mathrm{~km}^{2}$ in 2012 (Fig. 1; Vaughan et al. 2013).

Ice thickness and volume. These variables are more difficult to measure than ice concentration. However,

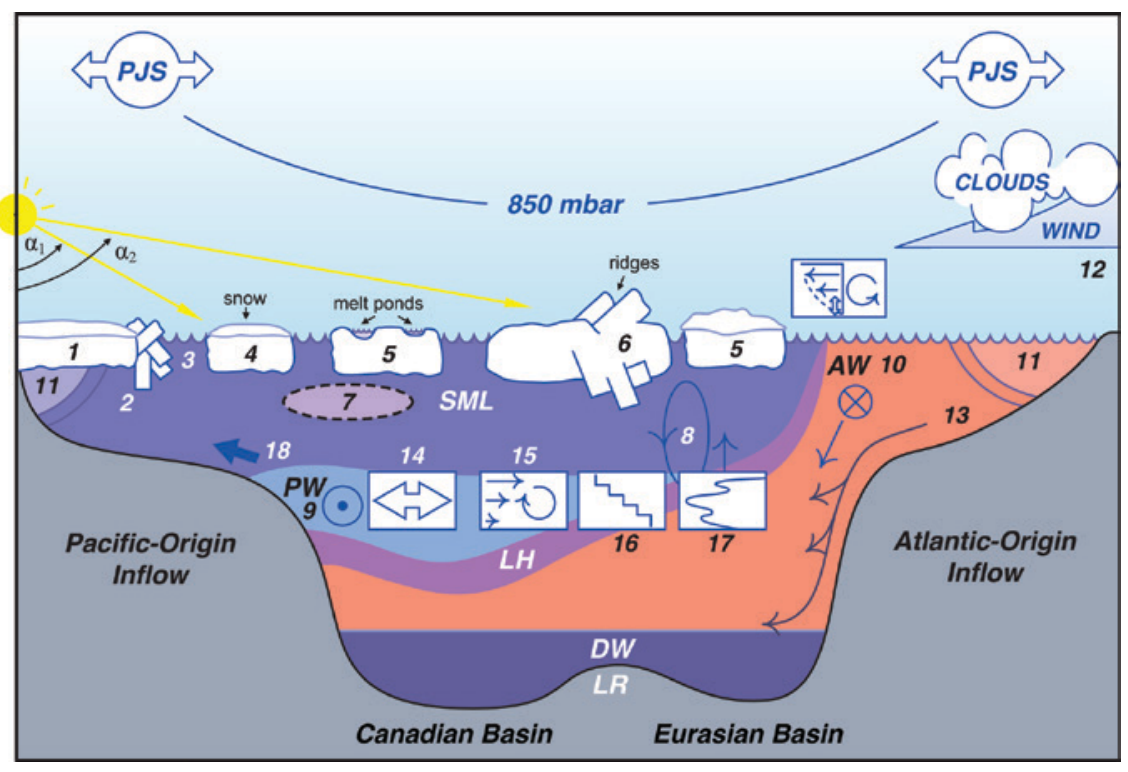

FIG. 2. Schematic diagram showing oceanic domains (shelves vs basins) and key processes (lateral and vertical) affecting ocean heat fluxes in the Arctic Ocean. Refer to the text for details about SML, NSTM, PW, LH, AW, and DW. Note that the areas of shelf and basin are roughly equal and that PW is largely confined within the Canadian basin. Distinct ice features include I) landfast ice, 2) ridged (stamukhi) ice, 3) flaw lead zones between landfast and floe ice, 4) first-year ice over shelf regions, 5) first-year ice over basins, and 6) multiyear and ridged ice over basins. Oceanic processes include 7) formation of the NSTM, 8) free and forced convection, 9) the subduction and circulation of PW, I0) the subduction and circulation of AW, II) coastal-trapped flows of river and low-salinity inflows, 12) wind forcing, 13) the drainage of shelf-modified waters to depth, 14) mixing due to tides and internal waves, 15) mixing due to shear, (6) double diffusion, 17) thermohaline intrusions, and (8) shelf-break upwelling. The polar vortex is schematically shown by the height of the $850-\mathrm{mb}$ surface and is bounded by the polar jet stream (PJS). The regional variation in solar angle by latitude and season is shown by the angles $\alpha_{1}$ and $\alpha_{2}$. Application of logistics and specific instrumentation (e.g., ships, ice camps, satellite remote sensing, gliders AUVs, ITPs) will depend critically on matching regional and seasonal challenges with appropriate technologies. ice draft data from submarines and upwardlooking moored sonars (Rothrock et al. 2008; Kwok and Rothrock 2009) and estimates of ice thickness from satellite altimetry (Kwok et al. 2009; Laxon et al. 2013) and airborne electromagnetic sensing (Haas et al. 2010) show that thickness and volume are both dropping rapidly (Fig. 1c; Hansen et al. 2013; Krishfield et al. 2014). Average sea ice thickness decreased by $1.75 \mathrm{~m}$ between 1980 and 2008 (Kwok and Untersteiner 2011). A sea ice reanalysis study utilizing the PanArctic Ice Ocean Modeling and Assimilation System (PIOMAS) suggests a rate of volume loss of $2.8 \times 10^{2} \mathrm{~km}^{3} \mathrm{yr}^{-1}$ between 1979 and 2010 (Schweiger et al. 2011); this dataconstrained model time series highlights the accelerated volume loss during the last decade in which measurements are available from satellite altimeters. If we interpret this loss as a purely thermodynamic 
response to changing heat transfers from the atmosphere and/or ocean, the required excess net energy flux into the ice pack averaged over these 28 years is about $1 \mathrm{~W} \mathrm{~m}^{-2}$ (Kwok and Untersteiner 2011). The above data apply mainly to the central Arctic basins, and few data are available for ice-thickness change on the vast continental shelves. Existing data do suggest, however, that change has been much less dramatic in the predominately first-year ice here than in the multiyear ice domain (Melling et al. 2005).

Ridged and multiyear ice. A quasi-equilibrium thickness for thermally conditioned multiyear ice is attained when the cold-season accretion of ice by conductive flux (which is inversely proportional to ice thickness) is matched by warm-season ablation due to radiative and oceanic fluxes (which are independent of its thickness) and, historically, is about $3 \mathrm{~m}$ for an average seasonal cycle of climatic forcing in the High Arctic (Maykut and Untersteiner 1971; Flato and Brown 1996). Theoretical exploration of sensitivities reveal that it is difficult to push the calculated result above $3 \mathrm{~m}$ but that changes in snow depth and ocean heat flux can easily bring the number down.

Despite these thermodynamic constraints, narrow zones of much thicker ice (ridges) that develop via the fracturing of level ice and piling of its fragments in response to wind forces are common in pack ice (Tucker et al. 1979; Wadhams and Horne 1980). Ridges commonly 10 or more times the maximum thickness of thermodynamically constrained, ice can form within a few hours (Amundrud et al. 2004). Subsequent thermal deterioration of such thick ice proceeds at an estimated $6 \mathrm{~m} \mathrm{yr}^{-1}$, so that remnants of a 30-m ridge may persist for 5 years (Amundrud et al. 2006). Such remnants, however, are dispersed and are of relatively small $(15-50 \mathrm{~m})$ lateral scale and cannot therefore explain the extensive areas of multiyear ice above 3-m thickness mapped in the Arctic since the first under-ice topographic surveys by submarine sonar (Lyon 1963; Bourke and Garrett 1987). Moreover, floes averaging $10 \mathrm{~m}$ or more in thickness on kilometer scales remain common in some areas of the Arctic even in the 2010s (H. Melling 2015, unpublished data). The "stamukhi" zone, marking the interface between fast ice and mobile pack ice, is the most plausible source for their continued genesis. Here, cyclic offshore/onshore and shearing movements of the pack in response to storms facilitate the creation of young ice in flaw leads and its subsequent compression into broad expanses of very thick ice rubble near the grounding line (cf. Kovacs and Mellor 1974). The patterns of wind and ice circulation favor the North American side of the Arctic margin for high ice pressure and rubblebuilding potential (Thorndike and Colony 1982; Colony and Thorndike 1984), in particular northern Greenland, the western Canadian polar shelf, and the northern Alaskan shelf. The role of ridge building in creating very thick multiyear ice floes has been largely overlooked. This creation process is storm driven and so should be relatively insensitive to the direct effects of atmospheric warming. The rate of ablation under present conditions is far too slow to eliminate hummock fields in one thaw season. It is therefore quite plausible that such ice will remain as a remnant of the perennial polar pack after thermally formed multiyear ice has disappeared.

Snow cover. The presence of a thermally insulating snow cover reduces the heat exchange between the ocean and the atmosphere. Snow is also an excellent reflector of solar radiation, with a wavelengthintegrated albedo of about 0.85 compared with $0.5-$ 0.7 for bare ice (Perovich et al. 2002). In spring most of the Arctic ice pack is covered by an optically thick snow cover (Sturm et al. 2002), allowing less than $1 \%$ of the incident solar radiation to be transmitted to the ocean (Light et al. 2008). As the snow cover melts, the albedo decreases and more sunlight is absorbed in the ice and in the upper ocean (Perovich and Polashenski 2012), which increases surface melting, bottom melting, and heat storage in the upper ocean. With the development of melt ponds in summer, an even greater fraction of incoming solar radiation is absorbed in the upper ocean (Itoh et al. 2011). As sea ice thins, the propensity for melt ponds to develop into melt holes increases, with both physical and biological impacts (Lee et al. 2011). Future sea ice scenarios indicate later freeze-up and more first-year ice, but the state of the snow cover is unclear. The time of year of snow accumulation is important: snow accumulating in autumn greatly reduces ice growth and delays melt, while snow accumulating in late winter has little effect on ice growth, but delays melt and ultimately generates more melt ponds. Webster et al. (2014) show large decreases in snow depth in the western Arctic compared to observations made from 1954 to 1991 (Radionov et al. 1997; Warren et al. 1999); they also show a negative correlation between snow depth and date of freeze-up. The largest reductions of snow depth were 56\% in the Beaufort and Chukchi Seas. A thinner snow cover on first-year ice will have competing thermodynamic effects: in winter, there will be greater heat loss to the atmosphere and more ice growth; but in summer, rapid 
snow loss will cause a reduction in albedo during the beginning of melt and an increase in solar heat input to the ice and ocean. A key question under study is whether a thinner spring snow cover leads to enhanced meltwater drainage and less pond coverage, resulting in increased albedo later in the melt season.

Ice velocity. Ice velocity ("drift") can be measured at high sampling rates (minutes to hours) using Doppler sonar (Melling et al. 1995) and satellite-tracked icemounted buoys (e.g., Rigor et al. 2000) and at longer periods by feature tracking in sequential satellite imagery (Fily and Rothrock 1987; Kwok et al. 1998). From analyses of the sparsely sampled record of buoy drift archived by the International Arctic Buoy Programme, Rampal et al. (2009) reported increases in average drift speed between 1978 and 2007 of $17 \%$ $\pm 4.5 \%$ decade $^{-1}$ in winter and $8.5 \% \pm 2.0 \%$ decade $^{-1}$ in summer. In basin-scale satellite motion fields, Spreen et al. (2011) found that the spatially averaged winter ice drift speed increased from 1992 to 2008 by $10.6 \%$ $\pm 0.9 \%$ decade $^{-1}$, but varied regionally. An analysis by Kwok et al. (2013) of 33 years of satellite-derived ice motion (1982-2009) found the largest spatially averaged trends in drift speeds between 2001 and 2009 in both winter $\left(+23.6 \%\right.$ decade $\left.^{-1}\right)$ and summer $(+17.7 \%$ decade $\left.^{-1}\right)$. These trends could not be explained by changes in wind speeds; instead, they coincide with the years of rapid ice thinning and the reduction in multiyear sea ice coverage during 2001-09, suggesting a response to changes in ice mechanics including reduced resistance to deformation. Altered characteristics in the oceanic boundary layer related to internal hydraulic interaction can also modify ice-ocean drag and therefore the drift response of ice to a given wind forcing (e.g., Pite et al. 1995). Increased wind-forced ice drift may contribute to higher mixing rates in the surface layer and, therefore, increased entrainment of heat to the ice base from warm subsurface ocean layers. However, changes in ice mechanics will also affect ice base roughness in complex ways, so that the net effect on upper-ocean turbulence is presently uncertain.

\section{HEAT TRANSPORT IN THE ARCTIC OCEAN: DESCRIPTION AND MECHANISMS. The}

provision of oceanic heat to the Arctic sea ice is a complicated, multistep process involving heat flows through lateral, top, and bottom boundaries, lateral distribution within the Arctic, and vertical fluxes to the surface mixed layer (SML) and base of the sea ice. Changes in any of these steps will impact the final contribution of oceanic heat to the sea-ice mass budget.
Heat input to the Arctic Ocean. Heat enters the Arctic Ocean as Atlantic Water (AW) through the Fram Strait and Barents Sea; as Pacific Water (PW) through the Bering Strait; as sensible and radiative fluxes into the upper ocean through thin ice, open water, and leads; and as summer pulses of warm river water. Each of these has a seasonal cycle. There is also a small geothermal heat flux $\left(<0.1 \mathrm{~W} \mathrm{~m}^{-2}\right.$; cf. Langseth et al. 1990; Carmack et al. 2012) through the seabed, not discussed further herein.

AtMOSPHeRIC HeAT INPUT. The Arctic upper ocean and sea ice cover receives net heat input in summer, as shortwave radiation and sensible heat fluxes directly heat the sea ice (including its snow layer), and the surface water in leads, under thin ice and below surface melt ponds (Itoh et al. 2011). The seasonal and shorter-term variability of individual atmospheric flux components can be of order $10^{2}-10^{3} \mathrm{~W} \mathrm{~m}^{-2}$ (e.g., Lindsay 1998; Persson 2012; Serreze et al. 2007). Even the measurement uncertainty on individual flux terms is at least $4-6 \mathrm{~W} \mathrm{~m}^{-2}$ (e.g., Persson et al. 2002, their Table 5) and, considering the differences between various estimates (e.g., Lindsay 1998; Serreze et al. 2007; Persson 2012; Kay and L'Ecuyer 2013), the total uncertainty of the individual flux terms is at least on the order of $10 \mathrm{~W} \mathrm{~m}^{-2}$. Most of the heat input to the upper ocean in summer is lost during autumn and winter when downwelling shortwave radiation becomes small or zero, and net longwave radiation and turbulent sensible heat fluxes cool the surfaces of both open water and the ice and snow (e.g., Serreze et al. 2009; Bekryaev et al. 2010). In autumn and winter, ocean sensible heat is transported to the air-ocean and air-ice interfaces by upper-ocean mixing and by conduction through the ice; however, measurements from recent years show that some of the heat gained by the upper ocean in summer is stored into the winter and can slow the growth of sea ice (e.g., Jackson et al. 2010, 2012).

AtLANTIC WATER. Warm and salty water originating in the North Atlantic enters the Arctic Ocean through Fram Strait and the western Barents Sea, resulting in waters warmer than $0^{\circ} \mathrm{C}$ spreading throughout the basin at depths between roughly 200 and $800 \mathrm{~m}$ (e.g., Aagaard 1989; Rudels et al. 1994; McLaughlin et al. 2009; Fig. 3). Ocean current measurements in Fram Strait during 1997-2000 documented a total northward volume transport of $9 \pm 2$ Sverdrups (Sv; $1 \mathrm{~Sv} \equiv 10^{6} \mathrm{~m}^{3} \mathrm{~s}^{-1}$ ), with a corresponding northward heat transport that varies seasonally from $28 \pm 5 \mathrm{TW}$ in winter to $46 \pm 5 \mathrm{TW}$ in summer (Schauer et al. 
2004). Some of this heat recirculates to the south in Fram Strait, and the net annual AW heat flux into the central Arctic was estimated at $18 \pm 5 \mathrm{TW}$ for 1997-2000 with $0^{\circ} \mathrm{C}$ taken as a reference temperature (Schauer et al. 2004). This heat transported into the Arctic Ocean is supplied to the deep-ocean interior, yielding a basin average of $5 \mathrm{~W} \mathrm{~m}^{-2}$ heat flux (Pnyushkov et al. 2015). In contrast, the Barents Sea branch delivers little heat to the deep Arctic basins, as it cools and freshens rapidly in the western Barents Sea

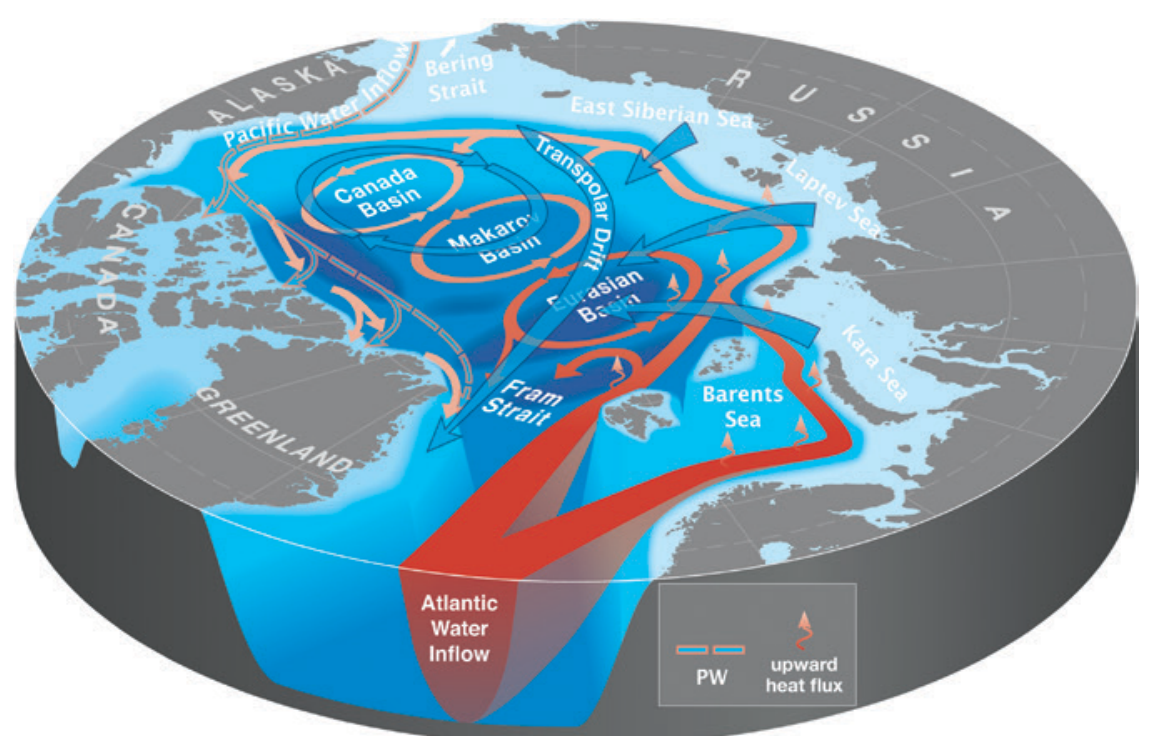

Fig. 3. Circulation of the surface water (blue), intermediate Pacific Water (pink/blue), and Atlantic Water (red) of the Arctic Ocean. prior to subducting along the Polar Front (Lien and Trofimov 2013). Enhanced inflow of warm AW was observed in the 2000s, resulting in exceptionally warm AW layer temperatures with no precedent since at least the 1950s (Polyakov et al. 2012b) and likely over the past 2000 years (Spielhagen et al. 2011). Observations demonstrated that that the temperature and salinity of the AW flowing into the Norwegian Sea were anomalously high (e.g., Holliday et al. 2008), suggesting that the ongoing warming of the Arctic Ocean interior will probably continue in the near future.

Lower-end estimates indicate that the recent AW warming episode could have contributed up to $150-200 \mathrm{~km}^{3}$ of sea ice melt per year, which would constitute about $20 \%$ of the total $900 \mathrm{~km}^{3} \mathrm{a}^{-1}$ negative trend in sea ice volume since 2004 (Ivanov et al. 2012). Ice thickness along the continental slope east of Svalbard is much less than that expected of firstyear ice, suggesting that AW has a direct impact on sea ice just after entering the Arctic (Onarheim et al. 2014). Local ice loss near the AW source thus can be a significant fraction of total net ice loss, and so an increased influx of AW could have an immediate effect on the Arctic ice volume budget.

PACIFIC Water. In the Canada basin the lateral injection of relatively fresh PW at intermediate (40-220 m) depths below the SML and above the AW greatly strengthens stratification to inhibit heat exchange between the AW and the SML (McLaughlin et al. 2004; Steele et al. 2004). This input varies seasonally: a warmer and fresher variety enters in summer as Pacific
Summer Water (PSW) at depths of 40-80 m, while a colder and more saline type enters in winter as Pacific Winter Water at depths of 80-220 m (Weingartner et al. 2005; Woodgate et al. 2005; Itoh et al. 2012, 2013). Woodgate et al. $(2006,2010)$ estimated the annual mean water and heat influx through Bering Strait at $0.8 \pm 0.1 \mathrm{~Sv}$ and $12.6 \pm 0.8 \mathrm{TW}$. The measured PW heat flux through Bering Strait increased in the 2000s (Woodgate et al.2012), contributing to heating and sea ice loss in the Canada basin (e.g., Shimada et al. 2006; Woodgate et al. 2010). Observations of transports through Bering Strait showed a doubling of heat flux from 2001 through 2007-enough to explain a third of 2007 summer Arctic ice volume loss (Woodgate et al. 2010). Shimada et al. (2006) suggested a positive feedback mechanism in which enhanced inflow of warm PSW into the Canada basin weakens the resistance of the large-scale ice cover to anticyclonic wind forcing, which in turn causes enhanced wind-driven transport of PSW off the shelf and into the central basin (Woodgate et al. 2010; Timmermans et al. 2014). The importance of this mechanism is expected to increase with further ice decline.

RIVER INPUTS. The summer freshets from the large Siberian and North American rivers (Figs. 2 and 3) provide lateral inputs of warm, fresh, and buoyant water. The annual-averaged volume flux of all Arctic rivers is $0.9 \pm 0.1 \mathrm{~Sv}$, dominated by summer (MayOctober) discharge with a peak in June (Peterson et al. 2002). With summer discharge temperatures of order $15^{\circ} \mathrm{C}$, the associated heat flux is $3 \mathrm{TW}$ averaged 
over an entire year, with a peak of $12 \mathrm{TW}$ in June and July (Whitefield et al. 2015). On an annual average, this heat input is $10 \%$ of the sum of the AW and PW inflows. However, the strong seasonal cycle of river inputs and the dominance of discharge into the coastal domain of shallow shelf seas suggest that these inputs may have disproportionately large impacts on their proximate shelves through their effects on melting ice and affecting local albedo (Dean et al. 1994). The resulting increase in summer stratification will result in more heat being trapped in shallow upper layers, delaying ice formation in autumn.

Lateral fluxes within the Arctic Ocean. Observations suggest that the three main mechanisms responsible for transporting inflow waters through the basins are 1) topographically trapped boundary currents flowing along the upper slope, 2) thermohaline intrusions that spread outward from the boundary currents, and 3) mesoscale eddies that shed from unstable fronts along the boundaries.

BOUNDARY CURRENTS. The general circulation of intermediate layers (Fig. 3) is dominated by the narrow, topographically steered Arctic Circumpolar Boundary Currents (ACBC) along the continental slope and midocean ridges and by cyclonic gyres within the deep basins (e.g., Aagaard 1989; Rudels et al. 1994; Aksenov et al. 2011). Waters of Atlantic origin are carried along the Eurasian continental slope by two branches of the ACBC (Fig. 3). One branch enters the Eurasian basin through the Fram Strait (Fahrbach et al. 2001; Schauer et al. 2004, 2008; BeszczynskaMöller et al. 2011). The second AW branch flows into the Barents Sea and enters the deep Arctic Ocean mainly through the 600-m-deep St. Anna Trough in the northern Kara Sea (Fig. 3). North of the Kara Sea, the two branches converge and continue eastward along the slope (Fig. 3), forming a confluence area along the shelf slope between the St. Anna Trough and the Lomonosov Ridge with a distinctive thermohaline front between the two branches (Schauer et al. 2002). Moorings in 2002-11 showed a gradual, fourfold decrease of boundary current speed from 24 to $6 \mathrm{~cm} \mathrm{~s}^{-1}$ on the route between Fram Strait and the Lomonosov Ridge, accompanied by transformation of the flow from mainly barotropic in Fram Strait to baroclinic flow between Spitsbergen and the central Laptev Sea slope (Pnyushkov et al. 2015). The boundary current bifurcates over the Lomonosov Ridge (Woodgate et al. 2001); one branch continues into the Makarov basin, while another branch turns to follow the Lomonosov Ridge toward the Fram Strait.
The PW entering through Bering Strait crosses the Chukchi Sea and enters the Canada basin in the depth range 60-220 $\mathrm{m}$ (Weingartner et al. 2005; Watanabe and Hasumi 2009). While there is a tendency for this water to initially flow as a cyclonic boundary current (Fig. 3), coupling with the overlying anticyclonic Beaufort Gyre and the propensity for generating mesoscale eddies off Point Barrow act to weaken the boundary current and rapidly draw PW into the interior of the Canada basin [see Pickart (2004), Pickart et al. (2005), and Nikolopoulos et al. (2009) for details]; continued loss of sea ice is hypothesized to increase the offshore transport (Shimada et al. 2006). The direct influence of the Pacific inflow is confined to the Canadian basin (McLaughlin et al. 1996; Bluhm et al. 2015, manuscript submitted to Prog. Oceanogr.).

Theoretical considerations have suggested a topographically controlled behavior of the boundary current (e.g., Porter and Rattray 1964; Warren 1969), though several other mechanisms, including advection of potential vorticity, atmospheric wind forcing, density gradients, and freshwater fluxes, may also contribute to the maintenance of the boundary current (Aaboe and Nøst 2008; Aaboe et al. 2009; Aksenov et al. 2010, 2011; Spall 2013). For example, analysis of long-term mooring records demonstrated that 2008-10 changes in the thermohaline state of the eastern Eurasian basin led to a reverse (i.e., shallow to left) direction of the along-slope currents, thus altering the general perception on the commonly accepted cyclonic regime of AW circulation in the central Laptev Sea (Pnyushkov et al. 2015). In support of this finding, Lien et al. (2013) showed that wind forcing near the Barents Sea shelf break may partition the relative strengths of the Fram Strait and Barents branches of the boundary current.

THERMOHALINE INTRUSIONS. Large thermohaline intrusions (inversions in salinity and temperature; see Fig. 4) with typical thickness of 20-50 m extend thousands of kilometers over most of the Arctic Ocean, centered in depth around the AW temperature maximum but extending to depths of $1600 \mathrm{~m}$ or more (Carmack et al. 1998; Walsh and Carmack 2003; Rudels et al. 2009; McLaughlin et al. 2009; Kuzmina et al. 2011). The generation mechanism for these intrusions requires further study; however, their structure strongly implicates double-diffusive processes as driving and organizing agents (Walsh and Carmack 2003). Their existence depends on appropriate lateral gradients in temperature and salinity maintained by the continual input of new 
AW with different temperature and salinity properties from those of ambient waters (Carmack et al. 1998). These intrusions contribute to the transport of AW heat away from the boundary currents and into and across the deep basins (Carmack et al. 1997; Walsh and Carmack 2003; McLaughlin et al. 2009). The Walsh and Carmack (2003) conceptual model of double-diffusive driving of intrusions is distinct from other studies (Smith and Ferrari 2010) that have identified isopycnal stirring by submesoscale eddies as a production mechanism for intrusions. The correspondence between thermohaline structures and chemical constituents in the Canada basin shows that chemical tracers are also transported by the intrusions (Woodgate et al. 2007; McLaughlin et al. 2009). The spreading of AW by intrusions increases lateral transport of AW, but other processes must be active in the deep basins if this heat is to penetrate the halocline and then to reach the surface. The contribution of AW intrusions to the lateral distribution of heat that is ultimately supplied to the sea ice is not known but will be more significant during periods

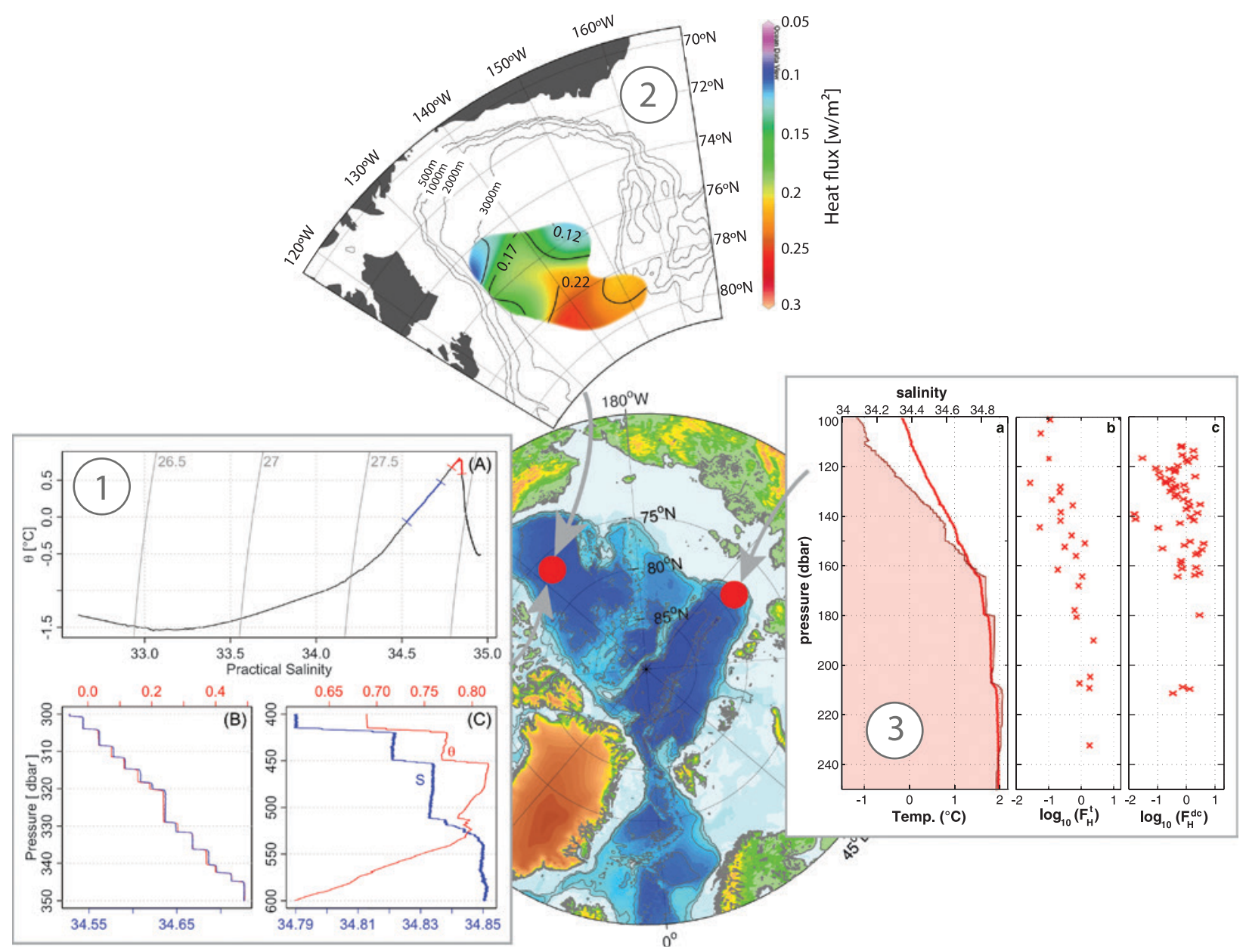

FIG. 4. Double-diffusive staircases and heat fluxes in the Arctic Ocean. I) Summary diagram for a conductivitytemperature-depth (CTD) profile collected in autumn 2012 at $77^{\circ} \mathrm{N}, 140^{\circ} \mathrm{W}$ in the Beaufort Sea. (a) Codependence of potential temperature and salinity, with blue indicating a subdomain containing staircase signatures and red indicating one with interleaving signatures. (b) Temperature and salinity profiles in the staircase region, showing roughly homogeneous layers a few meters thick, separated by much thinner interfaces. (c) Temperature and salinity profiles in the interleaving zone, revealing an alternating-sign pattern in temperature and salinity gradients on a scale of a few tens of meters, along with some thinner layers within the presumed intrusions. 2) Map of heat flux $\left(\mathrm{W} \mathrm{m}^{-2}\right)$ estimated by averaging over the 200-300-m-deep thermohaline staircases from the ITPs (Timmermans et al. 2008a). 3) Microstructure observations for a typical station from the Laptev Sea slope region. (a) Temperature is shown by shading and salinity is shown by the thick line. (b) Estimates of turbulent heat flux derived from microstructure measurements. (c) Double-diffusive heat flux derived from microstructure measurements of temperature and salinity. For further details, see Lenn et al. (2009). Horizontal axes in (b) and (c) use logarithmic scale. 
of thermohaline transition when double-diffusive forcing is stronger (cf. Carmack et al. 1998).

Mesoscale and submesoscale eddies and fronts. Mesoscale eddies in the Arctic Ocean (characterized by horizontal length scales between about 5 and $20 \mathrm{~km}$ ) play an important role in upper-ocean lateral and vertical fluxes of heat, mass, momentum, and tracers impacting the ocean interior (e.g., Hunkins 1974; Smith et al. 1984; Manley and Hunkins 1985; Manley 1987; Lankhorst 2006; Nudds and Shore 2011; Timmermans et al. 2008b; Zhao et al. 2014). The generation of mesoscale eddies over the continental slope also plays a role in the ventilation of the halocline layer (Aagaard and Carmack 1994; Kadko et al. 2008; Spall et al. 2008; Spall 2013) and serves as an efficient mechanism of water mass modification (Katsman et al. 2004).

Observations also reveal a complicated submesoscale flow structure (characterized by horizontal scales of $1 \mathrm{~km}$ or less) in the surface layer beneath sea ice in the Beaufort Sea and in ice-free conditions in the Chukchi Sea (Timmermans et al. 2012; Timmermans and Winsor 2013). The depth and properties of the SML are set not only by surface buoyancy fluxes and shear but also by secondary submesoscale flows that develop at lateral density fronts generated by spatial variability of fluxes and advection. Collapse of these fronts and subsequent restratification result in the formation of multiple layers, which tend to constrain surface warming to shallower depths. Two opposing consequences for sea ice are possible: layering may limit the effects of forced convection and shear at the surface, while submesoscale instabilities may contribute to higher mixing levels in the surface layer. Vertical velocities of submesoscale flows can be of order $10^{-4} \mathrm{~m} \mathrm{~s}^{-1}$ (Thomas et al. 2008) — an order of magnitude larger than typical vertical velocities associated with the mesoscale flow field. Therefore, vertical exchanges of properties between the surface layer in contact with sea ice and the underlying halocline are likely to be driven, at least in part, by submesoscale processes.

BATHYMETRIC CONTSTRAINTS INFLUENCING HEAT FLUX. The trends and processes discussed above are strongly dependent upon regional bathymetry (cf. Fig. 2). For example, the Arctic Ocean is approximately half continental shelf and half basin-and-ridge complex (Jakobsson et al. 2012), with important implications for water mass distribution and the relative importance of different processes. Boundary currents track the upper-continental slope and are thus largely confined to the deep basins (Rudels et al. 1999). Likewise, thermohaline intrusions and double diffusion are important only in the deep basins, and only when a pulse of "new" water is carried into the basin by boundary currents (Carmack et al. 1998; Walsh and Carmack 2003; Polyakov et al. 2012b). Ridge systems are sites of large-scale fronts and intensified circulation and mixing (Table 1; Shimada et al. 2005; Bluhm et al. 2015, manuscript submitted to Prog. Oceanogr.). The recent trend of summer ice retreat beyond the shelf into the basin now allows direct forcing by the wind of shelf-basin exchange (cf. Carmack and Chapman 2003; Bluhm et al. 2015, manuscript submitted to Prog. Oceanogr.). Regionality will thus play a major role in the evolution of ice cover in the new Arctic.

Upward heat fluxes to the ocean surface and sea ice. Heat input as seasonal insolation and sensible heating and as warm, buoyant river inputs is immediately available to the ice through direct contact with floe edges and advection under floes. Through most of the Arctic Ocean, however, heat input as AW and PW is separated from the surface by a layer of relatively cold and fresh water that reduces the direct impact of these heat sources on sea ice. One notable exception is the Nansen basin where, near the Fram Strait gateway, near-surface AW heat results in a significant reduction in sea ice thickness along the continental slope north and northeast of Svalbard (Onarheim et al. 2014). In Table 1 we summarize the known processes for heat delivery in these two depth ranges: surface mixed layer and stratified subsurface ocean.

SURFACE MIXED LAYER. The SML is a medium for storage, distribution, and release of seasonal heat acquired locally at the ocean surface. Most ice-mass loss in spring and summer (Fig. 5) occurs from the bottom in response to warming of the SML (Perovich et al. $2007,2008,2011,2014 b)$, suggesting that any process contributing to warming the SML can increase the seasonal loss of ice and retard growth in the following autumn.

Solar radiation is the main source of heat to the SML (e.g., Maykut and McPhee 1995; McPhee et al. 2003; Perovich et al. 2007, 2008, 2011, 2014b). In April-June, solar radiation enters the surface waters through leads and melt ponds, warming the SML to above freezing temperatures (Jackson et al. 2012). The SML begins to shoal in June or July once enough sea ice melt or river runoff has entered the surface to 
TABLE I. Regional estimates of upward heat fluxes $F_{h}\left(W_{m^{-2}}\right) . M M P=M c L a n e$ moored profiler. $X C P=e x-$ pendable current profiler.

\begin{tabular}{|c|c|c|c|c|c|}
\hline Region & Topography & Depth level & $\boldsymbol{F}_{h}$ & Method & Reference \\
\hline \multicolumn{6}{|c|}{ Eastern Arctic Ocean } \\
\hline Yermak Plateau & Steep & Halocline & 25 & Microstructure profiles & Padman and Dillon (1991) \\
\hline Yermak Plateau & Steep & Ice-ocean interface & 22 & Turbulent flux buoy & McPhee et al. (2003) \\
\hline \multirow[t]{2}{*}{ North of Svalbard } & \multirow[t]{2}{*}{ Steep } & Ice-ocean interface & $O(100)$ & \multirow{2}{*}{$\begin{array}{l}\text { Eddy covariance, } \\
\text { microstructure profiles }\end{array}$} & \multirow[t]{2}{*}{ Sirevaag and Fer (2009) } \\
\hline & & Halocline & $O(100)$ & & \\
\hline North of Svalbard & Slope & Halocline & $2-4$ & Microstructure profiles & Fer et al. (20I0) \\
\hline Laptev Sea & Slope & $\begin{array}{l}\text { Above AW core } \\
(>250 \mathrm{~m})\end{array}$ & $O(I)$ & Microstructure profiles & Lenn et al. (2009) \\
\hline Laptev Sea & Slope & $\begin{array}{l}\text { Above AW core } \\
(100-300 \mathrm{~m})\end{array}$ & $5-10$ & DDC estimates, MMP & Polyakov et al. (20I2a) \\
\hline \multirow[t]{2}{*}{ Amundsen basin } & \multirow[t]{2}{*}{ Interior } & Upper CHL & 0.05 & \multirow[t]{2}{*}{ Microstructure profiles } & \multirow[t]{2}{*}{ Fer (2009) } \\
\hline & & SML & 0.2 & & \\
\hline Amundsen basin & Interior & $\begin{array}{l}\text { Between SML and } \\
\text { AW core }\end{array}$ & $O(5)$ & $\begin{array}{l}\text { ITP, heat content } \\
\text { difference }\end{array}$ & Polyakov et al. (2013) \\
\hline Amundsen basin & Interior & $\begin{array}{l}\text { Thermohaline } \\
\text { staircase above AW } \\
\text { core }(200-260 \mathrm{~m})\end{array}$ & $0.05-0.6$ & $\begin{array}{l}\text { Microstructure profiles, } \\
\text { DDC estimates }\end{array}$ & Sirevaag and Fer (20I2) \\
\hline \multicolumn{6}{|c|}{ Western Arctic Ocean } \\
\hline Beaufort Sea & Interior & $\begin{array}{l}\text { Above AW core, } \\
320-430 \mathrm{~m}\end{array}$ & $0.02-0.1$ & Microstructure profiles & Padman and Dillon (I99I) \\
\hline \multirow[t]{2}{*}{ Canada basin } & \multirow[t]{2}{*}{ Interior } & SML base & $0.3-1.2$ & \multirow{2}{*}{$\begin{array}{l}\text { Turbulent } \\
\text { measurements }\end{array}$} & \multirow[t]{2}{*}{ Shaw et al. (2009) } \\
\hline & & Ice-ocean interface & 0.2 & & \\
\hline \multirow[t]{2}{*}{ Chukchi borderland } & \multirow[t]{2}{*}{ Steep } & SML base & $2.1-3.7$ & \multirow{2}{*}{$\begin{array}{l}\text { Turbulent } \\
\text { measurements }\end{array}$} & \multirow[t]{2}{*}{ Shaw et al. (2009) } \\
\hline & & Ice-ocean interface & 3.5 & & \\
\hline Beaufort Gyre & Interior & $200-300 \mathrm{~m}$ & $0.2-0.3$ & $\begin{array}{l}\text { DDC estimates, } \\
\text { ITPs }\end{array}$ & Timmermans et al. (2008a) \\
\hline Canada basin & Interior & Ice-ocean interface & $30-40$ & Sensible heat & Perovich et al. (2008) \\
\hline Canada basin & Interior & $150-400 \mathrm{~m}$ & $<0.2$ & $\begin{array}{l}\text { XCP-/CTD-based } \\
\text { estimates }\end{array}$ & Guthrie et al. (20I3) \\
\hline
\end{tabular}

increase stratification (Maykut and McPhee 1995; Jackson et al. 2010) and, possibly, also because of the collapse of submesoscale fronts in the SML (Timmermans et al. 2012; Timmermans and Winsor 2013). This stratification can also trap the solar radiation immediately below the SML, creating the near-surface temperature maximum (NSTM) that is typically observed at depths of $10-30 \mathrm{~m}$ in summer (Fig. 6). In the transition from summer to fall, kinetic energy from storms, outgoing turbulent heat fluxes, and penetrative convection driven by brine rejection cause the SML to cool, deepen, and entrain water from the halocline, including the NSTM.

The depth of the SML is dependent on both thermodynamic [ice melt and growth and atmosphereice-ocean heat and water exchanges (e.g., Lemke and
Manley 1984)] and dynamic [wind-driven forcing (e.g., Rainville and Woodgate 2009)] processes. In summer, the depth of the SML ranges from about $10 \mathrm{~m}$ or less in the Beaufort Sea and Canada basin to $20 \mathrm{~m}$ in the Eurasian basin (Fig. 6). In winter, the regional contrast in SML depth between the Canada and Eurasian basins increases, with $25 \mathrm{~m}$ in the Canada basin and 75-100 $\mathrm{m}$ and deeper in the Eurasian basin (Peralta-Ferriz and Woodgate 2015, see their Fig. 6). The SML has shoaled over the last 30 years at an average rate of $0.5-1 \mathrm{~m} \mathrm{yr}^{-1}$ (PeraltaFerriz and Woodgate 2015), which is consistent with freshening and increased stratification due to sea ice melt (Yamamoto-Kawai et al. 2009). This increased stratification traps solar radiation at the NSTM so that solar radiation that used to melt ice in summer 
or early fall now melts ice in early winter (Jackson et al. 2012). The first winter when the NSTM was observed year-round in the Canada basin was 2007/08 (Jackson et al. 2010; Toole et al. 2010; Steele et al. 2011), suggesting negligible mixing between the upper halocline and the SML. This was not always the case in the Canada basin; Maykut and McPhee (1995) demonstrated disappearance of the NSTM in data from the 1970s. The NSTM is visible in the icetethered profile (ITP; Krishfield et al. 2008) data from the Eurasian basin at approximately 20-m depth in early September but is absent throughout the winter portion of the record (Fig. 6).

Stratified SUBSURfaCe OCEAN. Rates of entrainment of heat from the subsurface ocean interior into the SML follow an advective pattern with hot spots located near the source regions (i.e., Fram Strait for the AW and Bering Strait for the PSW) and farther downstream following the major oceanic pathways
(Fig. 3). The estimated vertical heat flux into the SML was about $0.1 \mathrm{~W} \mathrm{~m}^{-2}$ in the Canada basin in summer and as high as $2 \mathrm{~W} \mathrm{~m}^{-2}$ over the Northwind Ridge and southern Chukchi Plateau (Shaw and Stanton 2014; Cole et al. 2014). The AW heat in the Canada basin is separated from the SML by a temperature minimum between the AW and PSW. In the Eurasian basin the highest entrainment heat fluxes occur along the path of AW where the along-flow AW heat content gradient and the rate of loss of AW heat are high (e.g., McPhee et al. 2003; Untersteiner 1988; Sirevaag and Fer 2009) and the AW is in direct contact with the SML (Fig. 6). Bathymetry also plays a role in the distribution of vertical heat input to the SML (e.g., Padman and Dillon 1991; Lenn et al. 2009; Shaw et al. 2009; Sirevaag and Fer 2009; Rippeth et al. 2015). For example, McPhee et al. (2003) found large $\left(>20 \mathrm{~W} \mathrm{~m}^{-2}\right)$, AW heat fluxes to the ice over the Yermak Plateau where warm AW is found close to the bottom of the SML and mixing rates are high.

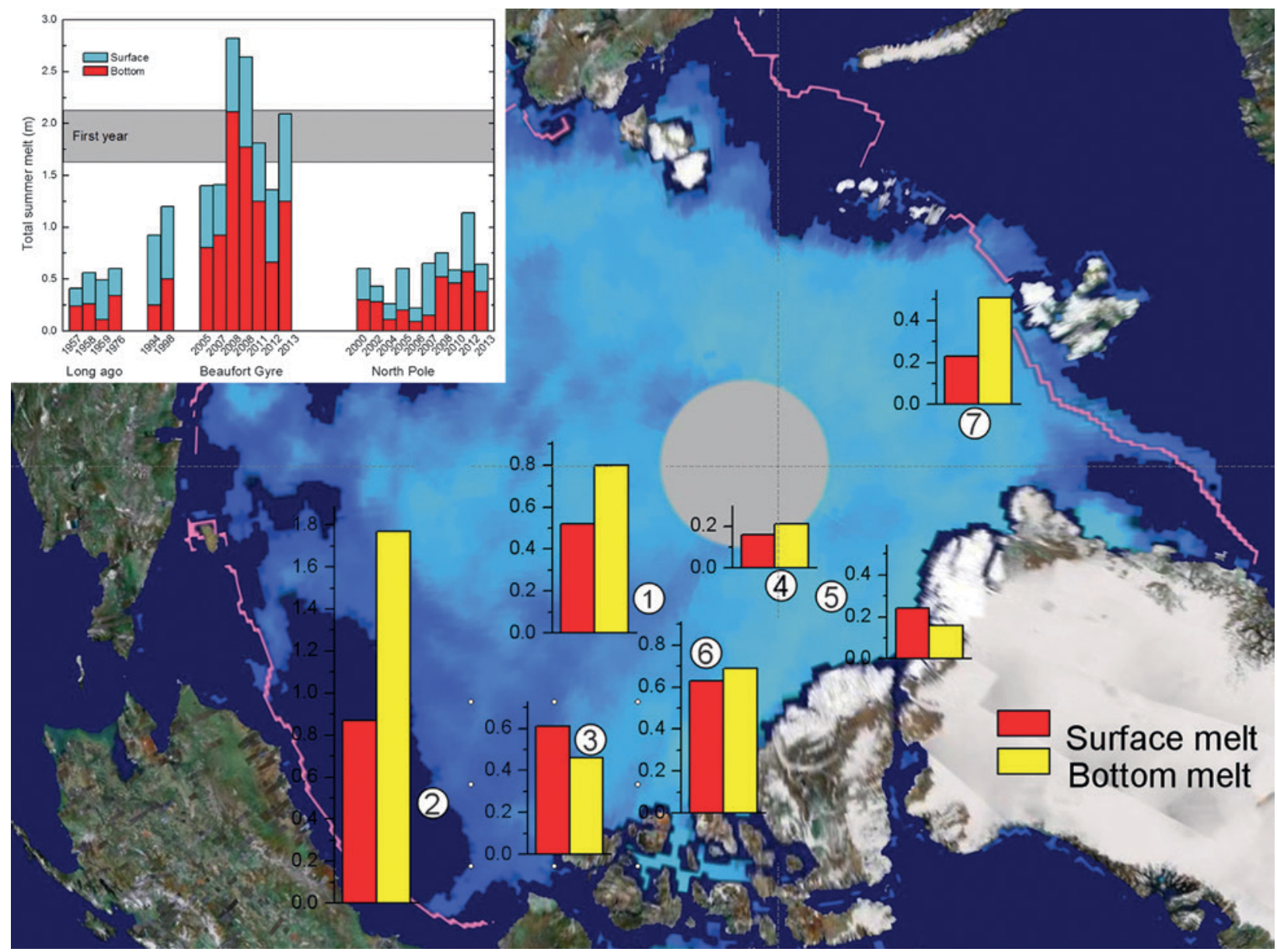

FIG. 5. Ice-mass buoy observations reveal the important role of bottom ice melt in areas of dramatic sea ice loss. Inset: 2008 observations placed in a long-term framework, demonstrating the major increase in bottom melt [modified from Perovich et al. (201I)]. 
Available observations suggest that, over much of the Arctic Ocean's deep basins, upward heat fluxes from the ocean interior to the top of the halocline (making it available for entrainment into the SML) are weak $\left(<1 \mathrm{~W} \mathrm{~m}^{-2}\right)$ (e.g., Table 1; Padman and Dillon 1987; Rainville and Winsor 2008; Fer 2009; Timmermans et al. 2008a). However, analyses of ITP records from the central Eurasian basin, away from steep topography, suggest that the delivery of AW heat to the overlying layers in the Eurasian basin interior can be important (Polyakov et al. 2013). Those authors showed that the transfer of heat from the upper pycnocline to the SML is highest in winter, with an average heat loss of 3-4 $\mathrm{W} \mathrm{m}^{-2}$ between January and April. It is likely that the increased heat loss from the AW layer to the SML in winter is caused by a combination of brine-driven convection that is associated with sea ice formation and larger vertical velocity shear below the base of the SML that is enhanced by winter storms.
VerTICAL MIXING IN THE STRATIFIED OCEAN BELOW THE SURFACE MIXED LAYER. Measured and inferred mixing rates in the stratified subsurface Arctic Ocean vary over several orders of magnitude (D'Asaro and Morison 1992; Padman 1995). Below the surface mixed layer, the water column over the deep basins is usually nonturbulent, with vertical mixing rates close to molecular levels (Padman and Dillon 1987; D'Asaro and Morison 1992; Rainville and Winsor 2008; Fer 2009; Lenn et al. 2009). Higher rates have been observed over the continental slope and ridges (D'Asaro and Morison 1992; Padman and Dillon 1991; Fer et al. 2010). The principal mechanisms for upward transport of ocean heat in the upper Arctic Ocean are shear instabilities and double diffusion, discussed separately below.

Shear instabilities. Dynamic instabilities driven by shear in the oceanic internal wave field account for most mixing and turbulent vertical fluxes in the

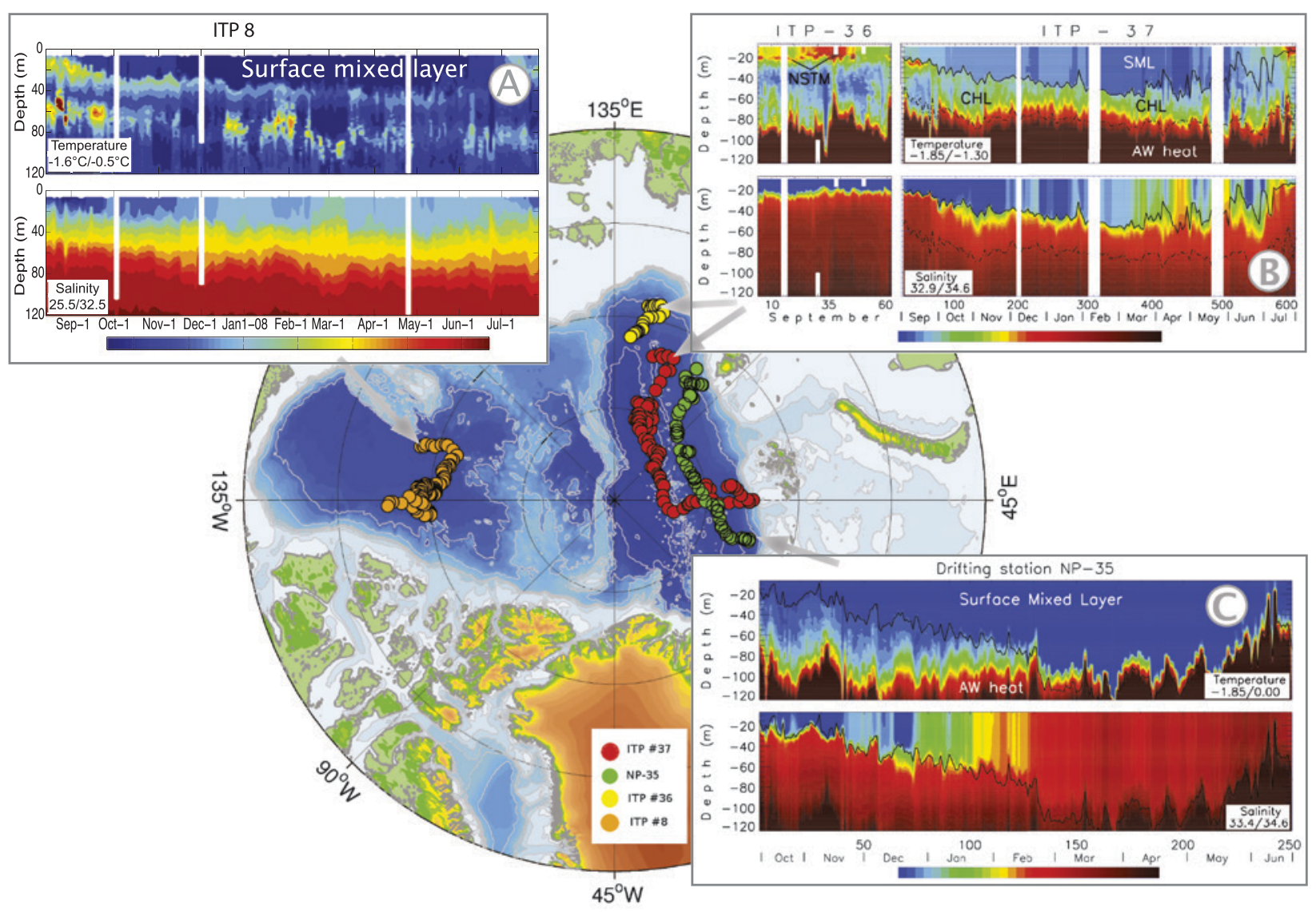

FIG. 6. (top) Potential temperature $\theta\left({ }^{\circ} \mathrm{C}\right)$ and (bottom) salinity $S$ along the ITP drifts. (a) Canadian basin. (b) Eastern and central Eurasian basin, ITP-36/-37 drifts, 2009/I0. Horizontal axis for both ITPs shows profile number complemented by approximate time. White segments indicate missing data. (right) Black solid line (ITP-37) shows the depth of the upper mixed layer; (bottom right) black broken line (ITP-37, salinity) shows the depth of the cold halocline layer (CHL) base. (c) Central Nansen basin. For all insets: the ranges of parameters used for color maps are shown in white inserted windows; the first (last) color scale is used for values less (more) than the identified range. Data for (a) and (b) are available from www.whoi.edu/itp. 
stratified ocean away from stress boundaries (Munk and Wunsch 1998). Major sources of oceanic internal waves are wind forcing and tidal interactions with bathymetry (e.g., internal lee wave generation and breaking). In the Arctic, the energy of near-inertial waves forced by wind and ice-ocean stresses depends on not only the strength of winds but also on the characteristics of the ice pack (e.g., Rainville and Winsor 2008; Fer 2014). The fraction of the nearinertial energy flux penetrating deep into the ocean and contributing to mixing is uncertain. Poststorm observations from the Amundsen basin showed an elevated halocline-average turbulent kinetic energy dissipation rate that decayed approximately at a rate implied by the reduction of near-inertial wave energy over time (Fer 2014). The energy of internal tides depends on proximity to barotropic tide forcing, which is spatially heterogeneous [Fig. 7, adapted from Padman and Erofeeva (2004)], and on the ability of baroclinic tides to propagate away from the source. In the central Canada basin, a region of very weak mixing (Padman and Dillon 1987), internal wave energy is, historically, very low (Levine et al. 1985), as would be expected from the high sea ice concentration and weak tidal forcing. In contrast, high mixing rates over the Yermak Plateau in the eastern Arctic Ocean (Table 1: Padman and Dillon 1991) correlate with the presence of energetic internal waves (Czipott et al. 1991; Fer et al. 2010) that appear to have a tidal origin.

In the new Arctic, with lower ice concentration and mass, it is almost certain that near-inertial wave energy is significantly higher than found in older studies. For example, mooring measurements over the continental shelf indicate that the onset of the seasonal ice cover damps near-inertial energy (Rainville and Woodgate 2009), inferring reduced generation of these waves. Ice cover also increases the dissipation of internal wave energy (Morison et al. 1985), especially at high ice concentrations where internal ice stresses are significant. Halle and Pinkel (2003), using data from the Beaufort Sea during winter, 1993/94, found that near-inertial internal wave generation (and presumably air-ocean coupling) is enhanced, relative to fully open-water conditions, when ice floes are present but sufficiently loose and mobile. The contribution of the near-inertial energy in mixing the deeper water column is, however, uncertain: a series of internal wave measurements at many locations shows that deep-ocean internal wave energy and associated mixing have not increased over the last two decades (Guthrie et al. 2013).

Barotropic tidal currents in the Arctic range from negligible in the deep Canada basin to over $1 \mathrm{~m} \mathrm{~s}^{-1}$ at some locations over the Eurasian shelf seas (Fig. 7). Tidal currents at the seabed may significantly affect the hydrographic structure of the Arctic, especially along the Eurasian continental slope where AW is still warm and trapped as a slope current (Holloway and Proshutinsky 2007). Tidal currents near the surface affect the sea ice cover through stresses at the ice-water interface and by periodic divergence of the ice pack, which influences ocean-atmosphere heat exchange and sea ice formation (Padman et al. 1992; Kowalik and Proshutinsky 1994). The few detailed measurements available near regions of large barotropic tidal currents show the generation of baroclinic tides (Plueddemann and Pinkel 1991; Plueddemann 1992; Padman and Dillon 1991; Padman et al. 1992; Kulikov et al. 2004, 2010; Pnyushkov and Polyakov 2012) and higher-frequency internal waves (Czipott et al. 1991; Zakharchuk 1999) that can lead to energetic mixing and large upward heat fluxes from the AW to the SML.

Both near-inertial and tidal currents vary on short time scales, with implications for observability. Rapid changes in near-inertial energy and shear can be seen in the continental shelf observations of Rainville and Woodgate (2009) and also in poststorm observations from drifting pack ice in the Amundsen basin (Fer 2014). Tidal currents vary seasonally (Pnyushkov and Polyakov 2012), increasing in the absence of ice cover, and also on the roughly 14-day time scale of the spring-neap cycle (e.g., Padman et al. 1992). In the new Arctic, we expect barotropic tidal currents to be similar to present values. However, internal tides are sensitive to stratification and low-frequency "background" flows, which affect both their generation and propagation characteristics. As with near-inertial waves, reduced sea ice may also reduce dissipation of baroclinic tidal energy through icewater friction (Pnyushkov and Polyakov 2012).

Double diffusion. Double diffusion is a process that drives vertical fluxes of heat and salt as a result of the difference in their molecular diffusivities, $\kappa_{T}$ and $\kappa_{S}$, respectively (Turner 1973). In the ocean, $\kappa_{T} / \kappa_{S}$ is of order 100. There are two flavors of double diffusion: salt fingering and diffusive convection (DC); both are active in thermohaline intrusion dynamics. The DC process occurs where temperature and salinity both increase with depth and is, therefore, a potential mechanism for transporting heat upward from warm and salty subsurface layers (Padman and Dillon 1987). Systematic and persistent fine-structure features such as "staircases" above the AW layer and the basin-scale interleaving suggest that double diffusion is an important mechanism in the Arctic, since 
the presence of other mixing processes would erase such features (Melling et al. 1984; Kelley et al. 2003).

Heat fluxes associated with DC are usually evaluated though laboratory-based flux laws based on easily observed stratification characteristics [see Robertson et al. (1995) for a summary]. Using these parameterizations, the estimated DC heat flux varies widely across the Arctic, from less than $0.3 \mathrm{~W} \mathrm{~m}^{-2}$ in the central Canada basin (Table 1; Padman and Dillon 1987; Timmermans et al. 2008a) to $1 \mathrm{~W} \mathrm{~m}^{-2}$ in deep-water locations in the Eurasian basin (Lenn et al. 2009; Sirevaag and Fer 2012), and possibly up to $5-10 \mathrm{~W} \mathrm{~m}^{-2}$ along the Eurasian basin margins (Polyakov et al. 2012a); see Fig. 4.

Differences between DC flux parameterizations result in significant uncertainty in predicted fluxes, and the flux laws also ignore the possible interaction

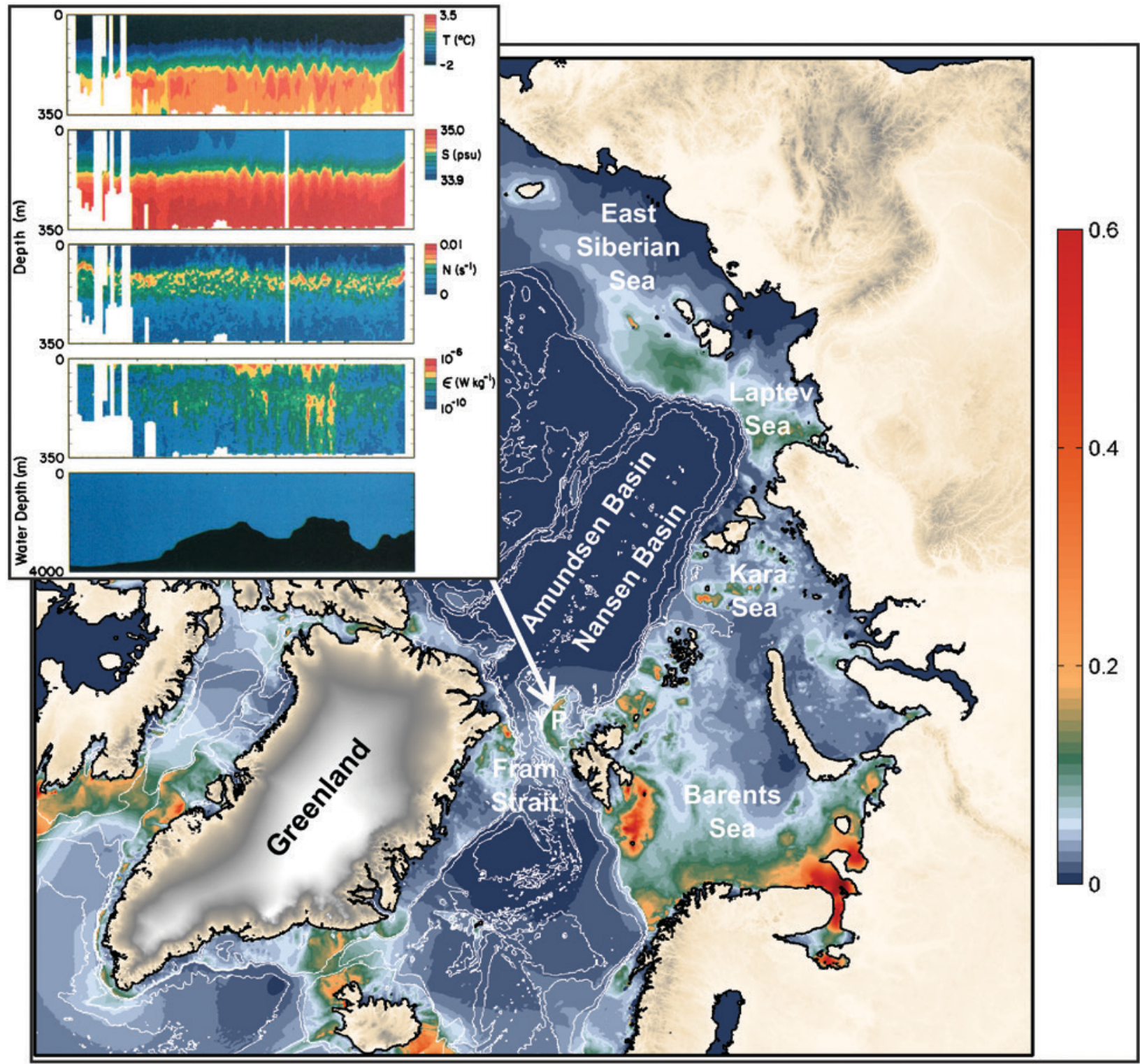

Fig. 7. Main map: mean barotropic tidal speed $\left(\mathrm{m} \mathrm{s}^{-1}\right.$; color scale on right), following Padman and Erofeeva (2004). White contours are 500-, 1000-, 2000-, and 3000-m isobaths. Inset: 25-day record of (from top to bottom) temperature $(T)$, salinity $(S)$, buoyancy frequency $(N)$, turbulent dissipation rate $(\varepsilon)$, and water depth as functions of time $(t)$ and depth $(z)$ as the Coordinated Eastern Arctic Experiment (CEAREX) Oceanography "O" Camp drifted across the Yermak Plateau in 1989; see Padman and Dillon (199I) for details. Tides in this region are primarily diurnal, seen in $T(t, z)$ and $S(t, z)$. (bottom) Tidal amplitudes vary with both position relative to topography and time within the approximately 14-day spring-neap cycle owing to the superposition of major tidal constituents. Plot of $\varepsilon(t, z)$ shows tidal modulation of mixing rates in the pycnocline and in the SML at the base of the sea ice. 
between DC and other sources of ocean variability. Padman (1994) proposed that nonlinear interaction between velocity shear and double-diffusive convection (DDC) might significantly increase the heat, salt, and momentum fluxes through a DC staircase. Polyakov et al. (2012a) used a year-long mooring profiler record from the Laptev Sea continental slope to show that the local velocity shear was largest across the interfaces. In the upstream areas of the Eurasian basin, where the along-slope currents and shear are strong (Schauer et al. 2004, 2008; Ivanov et al. 2009), the hypothesized interaction between DC and shear may play an even stronger role in setting the net vertical fluxes. Carpenter and Timmermans (2014) note that rotation and DC interface thickness are important parameters that are not captured by laboratory studies of DC fluxes.

In an evolving Arctic Ocean, DC fluxes will change as stratification varies. Parameterized fluxes depend on the buoyancy-frequency $N$ and the density ratio $R_{\rho}=(\beta \partial S / \partial z) /(\alpha \partial T / \partial z)$, where $\beta$ and $\alpha$ are the saline contraction and thermal expansion coefficients, respectively; a lower value of $R_{\rho}$ implies higher fluxes. Continued freshening of the upper ocean (cf. Proshutinsky et al. 2009) relative to the lower warm and salty layers of AW and PW would increase $R_{\rho}$ and reduce the DC heat flux. In contrast, the injection of warmer AW would decrease $R_{\rho}$. The importance of fluxes in key regions such as the AW boundary current along the Eurasian continental slope suggests that the changes in DC heat fluxes need to be factored into models of Arctic Ocean evolution.

Ice-albedo feedback mechanism. The ice-albedo feedback mechanism is traditionally considered to be the major Arctic feedback leading to accelerated warming in the Arctic. Here, warming leads to a reduction of ice and snow coverage and decreasing albedo, resulting in further snow and sea ice retreat (Manabe and Stouffer 1980). The most pronounced effect of this feedback, expressed as the strongest ocean-atmosphere upward heat flux and air temperature rise, may be found in areas of maximum ice retreat. However, the strongest upward heat fluxes occur in autumn, not summer, so that the strong warming of the atmosphere over the Arctic Ocean in autumn (e.g., Bekryaev et al. 2010) is, at least in part, a seasonally delayed manifestation of summer albedo feedback.

Recent observations provide new insight into the role of the ice-albedo feedback in climate change (e.g., Perovich et al. 2007, 2008, 2011, 2014a). Autonomous ice-mass balance buoy observations in 2008 (Fig. 5) demonstrate the important role of bottom ice melt in shaping changes of sea ice volume (cf. Toole et al. 2010). These results show that, in areas of dramatically reduced ice area like the Beaufort Gyre, bottom melt generally exceeds surface melt, implying that the ocean plays a critical role, even if only as a "collector" of solar energy. This increased bottom ice melt is related to increased solar heat input through numerous openings in sea ice cover (Perovich et al. $2007,2008)$. There is also large interannual variability with a general trend toward increasing bottom ice melt (see insert in Fig. 5), which suggests an increasing role of this mechanism with progressing global warming. Note, however, this is only for the summer melt season: equally, basal growth will exceed surface mass balance coming from precipitation and flooding of snowloaded ice during the rest of the year.

The recent dramatic reduction of Arctic ice, as well as anomalously high Arctic surface air temperatures, cannot be explained by the ice-albedo feedback mechanism alone. For example, Bekryaev et al. (2010) used observations collected in September 2007 to show a substantial-up to $2^{\circ} \mathrm{C}$ and more at some locations-water temperature increase in the upper25-m layer in the Siberian sector of the Arctic Ocean: they then compared the anomalous upper-ocean heat uptake with the annual horizontal atmospheric heat transport through $60^{\circ} \mathrm{N}$ and found that atmospheric heat transport greatly exceeds the total amount of heat accumulated in the ice-free area in summer 2007. This conclusion holds if the heat required to melt 2-m-thick ice over the area covered by oceanographic observations is added to the oceanic heat uptake. However, despite its relatively small magnitude, the atmospheric effect of oceanic warming caused by ice reduction may be important because of strong nearsurface atmospheric stratification leading to a large increase of atmospheric temperature near the surface (Deser et al. 2010).

A RESEARCH STRATEGY. The complexity of the processes by which ocean and atmospheric heat that is cycled through the upper ocean reaches the sea ice implies the need for interdisciplinary studies that combine atmospheric and sea ice scientists and oceanographers, and use novel technological approaches to acquire data in poorly sampled regions and seasons. We have identified four distinct scientific activities that, individually, address critical components of the Arctic ocean-ice system and, together, would provide significant progress in modeling sea ice evolution in projected future climates. These are 1) improved mapping of upper-ocean hydrographic 
properties, circulation, and heat fluxes to the ice, 2) process studies to quantify vertical heat flux as a function of more easily monitored variables, 3) longterm monitoring of upper-ocean state at key gateways within the Arctic Ocean, and 4) development of numerical capabilities focusing on parameterization of heat-flux mechanisms and their interactions.

Improved mapping. The most rapid loss of heat from the AW occurs along the continental slope and over the Eurasian basin, the hydrography of which is poorly sampled [see Fig. 2 from Polyakov et al. (2012b)]. A minimum requirement for improved mapping is to obtain data from different seasons for regions with distinct upper-ocean characteristics: these include the western and eastern Arctic for summer and winter for ranges of sea ice concentration and thickness. Ongoing shoaling of the SML and the critical role of heat-flux processes close to the ice implies acquisition of data up to the actual ice base. ITPs and other ice-mounted buoys provide one mechanism for acquiring these data through different seasons (e.g., Krishfield et al. 2008; Toole et al. 2010; Timmermans et al. 2012; Polyakov et al. 2013). With the reduced availability of thick and fairly stable multiyear floes, ITP deployments are more difficult; however, new developments now allow ITPs to be deployed in open water and freeze in winter.

Little information exists for the shallow inner coastal domain (roughly the inner 10-20 km), despite the important role of this domain in initiation of ice breakup and distribution of river inputs of freshwater and heat (Whitefield et al. 2015; Carmack et al. 2015). Ships cannot navigate easily in these regions, and present ice-tethered instruments are vulnerable to ice ridging in shallow water. Gliders and autonomous underwater vehicles (AUVs) may yield valuable information in these regions.

A broad spatial distribution of heat-flux estimates near the ice base, resolving changes from subtidal/ subinertial to annual time scales, is needed to quantify heat fluxes and identify processes that directly influence ice thermodynamics. Direct estimation of turbulent ocean fluxes using correlations between turbulent vertical velocity fluctuations and variations in ocean temperature, salinity, and horizontal velocity is the optimum methodology and has been used successfully at manned camps (e.g., McPhee 2008; McPhee et al. 2003). However, acquiring a broad distribution of long-term turbulent flux measurements from autonomous sites will require advances in technology (Toole et al. 2011).
Broad access to the Arctic remains a major limitation, including logistics of ships and aircraft for instrument deployment and restrictions related to territorial issues. For example, deployment of Lagrangian drifters of various types (e.g., ITPs and meteorological buoys) depends on season and ice conditions and therefore is often geographically limited leaving vast Arctic Ocean areas without sustained observations.

Process studies. Studies focused on the following specific processes and interactions are required to improve our conceptual understanding and ability to quantify ocean heat fluxes through parameterizations in ocean and coupled climate models.

- Ocean cycling of atmospheric heat input at the surface: Field campaigns are required to determine the partitioning of solar input to the ocean between ice melt, ocean warming, and retardation of ice growth. Dense measurements are needed to resolve the seasonal evolution of near-surface stratification and submesoscale processes that control mixing. Coordinated field- and modelingbased process studies in the spring to summer should refine our understanding of the timing of heat storage in the upper ocean and the release of this heat back to the ice and atmosphere through summer and fall. We need to quantify how seasonality in the upper-ocean stratification and mixing control heat release back to the ice and how these processes respond to variations in solar input controlled by the ice cover.

- Generation and propagation of internal gravity waves: An integrated modeling and observational study is required to develop maps of internal wave energy as a proxy for mixing by shear instabilities. The two principal internal wave sources-tides and wind forcing of near-inertial waves-have very different spatial characteristics (e.g., Kulikov et al. 2010). Concurrent measurements of ice concentration and internal wave frequency-wavenumber spectra over a broad range of ice concentration, roughness, and floe size, and underlying stratification including SML thickness, will identify the sensitivity of near-inertial energy input to the upper ocean. High-resolution 3D ocean models, with full atmospheric and tide forcing and a coupled sea ice model, can be used to identify generation sites, propagation characteristics for internal tides, interactions with the ice pack including changes to shear stresses and consequent 
dissipation of internal wave energy, and impacts on ice concentration.

- Double diffusion, including its interaction with the internal wave field: Direct turbulence measurements are required to confirm or refute the inferred presence of large double-diffusive heat fluxes in the Eurasian basin. By combining these measurements with high-resolution measured shear, the postulated nonlinear interactions between double diffusion and internal wave shear can be assessed. Alternative approaches, such as dye release and subsequent mapping by autonomous underwater vehicles, may provide additional insight. Direct numerical simulation and large-eddy simulation models for studying double-diffusive heat fluxes should be further developed.

- Intrusions: A process study on Arctic intrusions is needed to assess the lateral heat flux from the boundary currents into the deep basins. For regions that are seasonally ice free, gliders mounted with turbulence sensors (e.g., Fer et al. 2014; Peterson and Fer 2014) could map the turbulence properties within intrusions, augmenting broad spatial surveys with vertical microstructure profilers deployed through the ice pack. These data would form the basis of diapycnal flux parameterizations that can be applied to models of the evolving Arctic hydrography.

Long-term monitoring. Arctic Ocean "gateway" studies have provided valuable information on multiyear variability of ocean heat and freshwater fluxes through the Bering and Fram Straits, the Barents Sea, and the Canadian Arctic Archipelago (BeszczynskaMöller et al. 2011). Despite problems with estimates of oceanic heat fluxes using these observations (Schauer and Beszczynska-Möller 2009), they give insight, a basis for improved measurements, and an understanding of the regional oceanography for other applications. Similar long-term monitoring is required within the central Arctic Ocean at key locations where critical water mass transports and transformations take place. These sites include the outflow from the St. Anna Trough (where the Barents Sea branch of AW meets the Fram Strait branch) and sites in the central deep basins that experience decadal variability in the location of the PW/ AW fronts. Present technologies include long-term moorings and ice-tethered profilers. Requirements for the latter include improved sampling of data-sparse areas, including the eastern Arctic and improved seasonal coverage of specific regions.
Development of numerical capabilities. The wide spread of projected Arctic sea ice states in global coupled climate models indicates the need for improved numerical capabilities for Arctic modeling. Improved models are required over a broad range of scales, from direct numerical and large-eddy simulations of specific small-scale processes (e.g., double diffusion and boundary layer mixing under sea ice) to the mesoscale-to-basin length scales. For the latter, development of a data-constrained ocean state estimate for the most recent several decades, such as that developed by Nguyen et al. $(2011,2012)$, would provide information on optimal future data collection sites and critical data types. Recent modeling suggests that a lateral grid spacing of order $1 \mathrm{~km}$ and high vertical resolution is required to resolve processes such as eddy transport of heat from boundary currents into the deep basin interiors and distribution of river water across the continental shelves and through vertical mixing.

Ice models must be improved to provide a statistical representation of the small scales of floes and leads that determine heat, freshwater, and momentum exchanges between the atmosphere, ice (including snow layer), and ocean. The ice model must be capable of coupling at the small scales of oceanic variability identified in recent datasets and high-resolution models.

CONCLUSIONS. The retreat and thinning of the summer sea ice are the most visible indicators of the major physical changes underway in the Arctic Ocean (Kwok et al. 2009). While rates and even causes of ice loss remain under debate (Carmack and Melling 2011), it is probable that the further loss of sea ice will open the ocean to stronger atmospheric forcing and accelerate ongoing feedback processes. Recent observations and model results suggest that small changes in the ways that the ocean transports heat originating from the seasonal cycle of surface fluxes, plus advective inputs from the sub-Arctic oceans and rivers, could have a significant effect on current and future changes in Arctic ice cover. Advanced understanding and synthesis of complex ocean-ice-air interactions and associated feedbacks on broad time (minutes to interannual) and space (millimeters to global) scales are required to provide realistic projections of the fate of seasonal and perennial sea ice in the Arctic Ocean in the coming years and decades. With continued decline in sea ice cover, and enhanced coupling of the atmosphere to the ocean, the physical processes controlling the delivery, storage, and 
release of heat within the Arctic Ocean to its overlying ice cover are likely to increase in importance and must be studied and ranked if we are to reduce uncertainties in projections of the Arctic's role in weather and likely trajectories of future climate. In this document we identified critical processes, key questions, and required elements for a research agenda that combines field-based process studies, sustained observational programs, and modeling. Because physical systems within the Arctic Ocean impact biogeochemical processes and occur across sovereign state boundaries, true multidisciplinary, multiagency, and multinational efforts are required.

ACKNOWLEDGMENTS. The document reflects contributions and discussions from a Sydney Chapman Chair workshop entitled "An Untersteiner Workshop: On the Role and Consequences of Ocean Heat Flux in Sea Ice Melt," held 19-21 March 2013 at the International Arctic Research Center (IARC) at the University of Alaska Fairbanks. We deeply appreciate the logistics support offer by L. Hinzman, and staff of IARC, and financial support provided by IARC and by the College of Natural Science and Mathematics, University of Alaska Fairbanks.

\section{REFERENCES}

Aaboe, S., and O. A. Nøst, 2008: A diagnostic model of the Nordic seas and Arctic Ocean circulation: Quantifying the effects of a variable bottom density along a sloping topography. J. Phys. Oceanogr., 38, 2685-2703, doi:10.1175/2008JPO3862.1.

—, — , and E. Hansen, 2009: Along-slope variability of barotropic transport in the Nordic Seas: Simplified dynamics tested against observations. J. Geophys. Res., 114, C03009, doi:10.1029 /2008JC005094.

Aagaard, K., 1989: A synthesis of the Arctic Ocean circulation. Rapp. P.-V. Reun.- Cons. Int. Explor. Mer, 188, 11-22.

— climate: A perspective. The Polar Oceans and Their Role in Shaping the Global Environment, Geophys. Monogr., Vol. 85, Amer. Geophys. Union, 5-20.

Aksenov, Y., S. Bacon, A. C. Coward, and A. J. G. Nurser, 2010: The North Atlantic inflow to the Arctic Ocean: High-resolution model study. J. Mar. Syst., 79, 1-22, doi:10.1016/j.jmarsys.2009.05.003.

—, V. V. Ivanov, A. J. G. Nurser, S. Bacon, I. V. Polyakov, A. C. Coward, A. C. Naveira-Garabato, and A. Beszczynska-Moeller, 2011: The Arctic circumpolar boundary current. J. Geophys. Res., 116, C09017, doi:10.1029/2010JC006637.
Alexeev, V. A., and C. H. Jackson, 2013: Polar amplification: Is atmospheric heat transport important? Climate Dyn., 41, 533-547.

Amundrud, T. L., H. Melling, and R. G. Ingram, 2004: Geometric constraints on the evolution of ridged sea ice. J. Geophys. Res., 109, C06005, doi:10.1029/2003JC002251.

- $-\longrightarrow,-$, and S. E. Allen, 2006: The effect of structural porosity on the melting of ridge keels in pack ice. J. Geophys. Res., 111, C06004, doi:10.1029/2005JC002895.

Barber, D. G., and Coauthors, 2012: Consequences of change and variability in sea ice on marine ecosystem and giogeochemical processes during the 2007-2008 Canadian International Polar Year program. Climatic Change, doi:10.1007/s10584-012 -0482-9, in press.

Barnes, E. A., 2013: Revisiting the evidence linking Arctic amplification to extreme weather in midlatitudes. Geophys. Res. Lett., 40, 4728-4733, doi:10.1002 /grl.50880.

Bekryaev, R. V., I. V. Polyakov, and V. A. Alexeev, 2010: Role of polar amplification in long-term surface air temperature variations and modern Arctic warming. J. Climate, 23, 3888-3906, doi:10.1175 /2010JCLI3297.1.

Beszczynska-Möller, A., R. A. Woodgate, C. Lee, H. Melling, and M. Karcher, 2011: A synthesis of exchanges through the main oceanic gateways to the Arctic Ocean. Oceanography, 24, 82-99, doi:10.5670 loceanog.2011.59.

Bhatt, U. S., and Coauthors, 2014: Implications of Arctic sea ice decline for the earth system. Ann. Rev. Environ. Resour., 39, 57-89, doi:10.1146/annurev -environ-122012-094357.

Bluhm, B. A., K. N. Kosobokoba, and E. C. Carmack, 2015: A Tale of Two Basins: An integrated physical and biological perspective of the deep Arctic Ocean. Prog. Oceanogr., doi:10.1016/j.pocean.2015.07.011, in press.

Bourke, R. H., and R. P. Garrett, 1987: Sea ice thickness distribution in the Arctic Ocean. Cold Reg. Sci. Technol., 13, 259-280, doi:10.1016/0165-232X(87)90007-3.

Carmack, E. C., and D. C. Chapman, 2003: Winddriven shelf/basin exchange on an Arctic Shelf: The joint roles of ice cover extent and shelfbreak bathymetry. Geophys. Res. Lett., 30, 1778, doi:10.1029/2003GL017526.

— , and H. Melling, 2011: Warmth from the deep. Nat. Geosci., 4, 7-8, doi:10.1038/ngeo1044.

— - and Coauthors, 1997: Changes in temperature and tracer distributions within the Arctic Ocean: Results from the 1994 Arctic Ocean section. Deep-Sea 
Res. II, 44, 1487-1502, doi:10.1016/S0967-0645(97) 00056-8.

—, K. Aagaard, J. H. Swift, R. G. Perkin, F. A. McLaughlin, R. W. Macdonald, and E. P. Jones, 1998: Thermohaline transitions. Physical Processes in Lakes and Oceans, J. Imberger, Ed., Coastal and Estuarine Studies, Vol. 54, Amer. Geophys. Union, 179-186.

— W. Williams, S. Zimmerman, and F. A. McLaughlin, 2012: The Arctic Ocean warms from below. Geophys. Res. Lett., 39, L07604, doi:10.1029/2012GL050890.

—, P. Winsor, and W. Williams, 2015: The contiguous panarctic Riverine Coastal Domain: A unifying concept. Prog. Oceanogr., doi:10.1016/j .pocean.2015.07.014, in press.

Carpenter, J. R., and M.-L. Timmermans, 2014: Does rotation influence double-diffusive fluxes in polar oceans? J. Phys. Oceanogr., 44, 289-296, doi:10.1175 /JPO-D-13-098.1.

Cassano, E. N., J. J. Cassano, M. E. Higgins, and M. C. Serreze, 2014: Atmospheric impacts of an Arctic sea ice minimum in the Community Atmospheric Model. Int. J. Climatol., 34, 766-779, doi:10.1002 /joc.3723.

Cole, S. T., M.-L. Timmermans, J. M. Toole, R. A. Krishfield, and F. T. Thwaites, 2014: Ekman veering, internal waves, and turbulence observed under Arctic sea ice. J. Phys. Oceanogr., 44, 1306-1328, doi:10.1175/JPO-D-12-0191.1.

Colony, R., and A. S. Thorndike, 1984: An estimate of the mean field of Arctic sea ice motion. J. Geophys. Res., 89, 10623-10629, doi:10.1029/JC089iC06p10623.

Comiso, J. C., 2012: Large decadal decline in the Arctic multiyear ice cover. J. Climate, 25, 1176-1193, doi:10.1175/JCLI-D-11-00113.1.

- , and F. Nishio, 2008: Trends in the sea ice cover using enhanced and compatible AMSR-E, SSM/I, and SMMR data. J. Geophys. Res., 113, C02S07, doi:10.1029/2007JC004257.

Czipott, P. V., M. D. Levine, C. A. Paulson, D. Menemenlis, D. M. Farmer, and R. G. Williams, 1991: Ice flexure forced by internal wave packets in the Arctic Ocean. Science, 254, 832-835, doi:10.1126 /science.254.5033.832.

D’Asaro, E. A., and J. H. Morison, 1992: Internal waves and mixing in the Arctic Ocean. Deep-Sea Res., 39A, S459-S484, doi:10.1016/S0198-0149(06)80016-6.

Dean, K. G., W. J. Stringer, K. Ahlnäs, C. Searcy, and T. Weingartner, 1994: The influence of river discharge on the thawing of sea ice, Mackenzie River Delta: Albedo and temperature analyses. Polar Res., 13, 83-94, doi:10.1111/j.1751-8369.1994.tb00439.x.

Deser, C., R. Tomas, M. Alexander, and D. Lawrence, 2010: The seasonal atmospheric response to projected
Arctic sea ice loss in the late twenty-first century. J. Climate, 23, 333-351, doi:10.1175/2009JCLI3053.1.

Fahrbach, E., J. Meincke, S. Osterhus, G. Rohardt, U. Schauer, V. Tverberg, and J. Verduin, 2001: Direct measurements of volume transport through Fram Strait. Polar Res., 20, 217-224, doi:10.1111/j.1751 -8369.2001.tb00059.x.

Fer, I., 2009: Weak vertical diffusion allows maintenance of cold halocline in the central Arctic. Atmos. Oceanic Sci. Lett, 2, 148-152, doi:10.1080/16742834 .2009.11446789.

- 2014: Near-inertial mixing in the central Arctic Ocean. J. Phys. Oceanogr., 44, 2031-2049, doi:10.1175 /JPO-D-13-0133.1.

—, R. Skogseth, and F. Geyer, 2010: Internal waves and mixing in the marginal ice zone near the Yermak Plateau. J. Phys. Oceanogr., 40, 1613-1630, doi:10.1175 /2010JPO4371.1.

—, A. K. Peterson, and J. E. Ullgren, 2014: Microstructure measurements from an underwater glider in the turbulent Faroe Bank Channel overflow. J. Atmos. Oceanic Technol., 31, 1128-1150, doi:10.1175 /JTECH-D-13-00221.1.

Fily, M., and D. A. Rothrock, 1987: Sea ice tracking by nested correlations. IEEE Trans. Geosci. Remote Sens., GE-25, 570-580, doi:10.1109/TGRS.1987.289836.

Flato, G. M., and R. D. Brown, 1996: Variability and climate sensitivity of landfast Arctic sea ice. J. Geophys. Res., 101, 25 767-25 778, doi:10.1029/96JC02431.

Francis, J. A., and S. J. Vavrus, 2012: Evidence linking Arctic amplification to extreme weather in midlatitudes. Geophys. Res. Lett., 39, L06801, doi:10.1029 /2012GL051000.

Grassi, B., G. Redaelli, and G. Visconti, 2013: Arctic sea ice reduction and extreme climate events over the Mediterranean region. J. Climate, 26, 10 101-10 110, doi:10.1175/JCLI-D-12-00697.1.

Guthrie, J. D., J. H. Morison, and I. Fer, 2013: Revisiting internal waves and mixing in the Arctic Ocean. J. Geophys. Res. Oceans, 118, 3966-3977, doi:10.1002 /jgrc.20294.

Haas, C., A. Pfaffling, S. Hendricks, L. Rabenstein, J. L. Etienne, and I. Rigor, 2008: Reduced ice thickness in Arctic Transpolar Drift favors rapid ice retreat. Geophys. Res. Lett., 35, L17501, doi:10.1029 /2008GL034457.

-, S. Hendricks, H. Eicken, and A. Herber, 2010: Synoptic airborne thickness surveys reveal state of Arctic sea ice cover. Geophys. Res. Lett., 37, L09501, doi:10.1029/2010GL042652.

Halle, C., and R. Pinkel, 2003: Internal wave variability in the Beaufort Sea during the winter of 1993/1994. J. Geophys. Res., 108, 3210, doi:10.1029/2000JC000703. 
Hansen, E., S. Gerland, M. A. Granskog, O. Pavlova, A. H. H. Renner, J. Haapala, T. B. Løyning, and M. Tschudi, 2013: Thinning of Arctic sea ice observed in Fram Strait: 1990-2011. J. Geophys. Res. Oceans, 118, 5202-5221, doi:10.1002/jgrc.20393.

Holliday, N. P., and Coauthors, 2008: Reversal of the 1960 s to 1990s freshening trend in the northeast North Atlantic and Nordic Seas. Geophys. Res. Lett., 35, L03614, doi:10.1029/2007GL032675.

Holloway, G., and A. Proshutinsky, 2007: Role of tides in Arctic ocean/ice climate. J. Geophys. Res., 112, C04S06, doi:10.1029/2006JC003643.

Honda, M., K. Yamazaki, Y. Tachibana, and K. Takeuchi, 1996: Influence of Okhotsk sea ice extent on atmospheric circulation. Geophys. Res. Lett., 23, 3595-3598, doi:10.1029/96GL03474.

Hunkins, K. L., 1974: Subsurface eddies in the Arctic Ocean. Deep-Sea Res., 21, 1017-1033.

Hutchings, J. K., and I. G. Rigor, 2012: Role of ice dynamics in anomalous ice conditions in the Beaufort Sea during 2006 and 2007. J. Geophys. Res., 117, C00E04, doi:10.1029/2011JC007182.

Itoh, M., J. Inoue, K. Shimada, S. Zimmermann, T. Kikuchi, J. Hutchings, F. A. McLaughlin, and E. C. Carmack, 2011: Acceleration of sea ice melting due to transmitted heat through pounded ice area in the Arctic Ocean: Results of in situ observation from icebreakers in 2006 and 2007. Ann. Glaciol., 52, 249-260, doi:10.3189/172756411795931471.

_-, K. Shimada, T. Kamoshida, F. McLaughlin, E. Carmack, and S. Nishino, 2012: Interannual variability of Pacific Winter Water inflow through Barrow Canyon from 2000 to 2006. J. Oceanogr., 68, 575-592, doi:10.1007/s10872-012-0120-1.

— , S. Nishino, Y. Kawaguchi, and T. Kikuchi, 2013: Barrow Canyon volume, heat, and freshwater fluxes revealed by long-term mooring observations between 2000 and 2008. J. Geophys. Res. Oceans, 118, 43634379, doi:10.1002/jgrc.20290.

Ivanov, V. V., and Coauthors, 2009: Seasonal oceanic variability off Svalbard in 2004-06. Deep-Sea Res. I, 56, 1-14, doi:10.1155/2012/201818.

—, V. A. Alexeev, I. Repina, B. V. Koldunov, and A. Smirnov, 2012: Tracing Atlantic water signature in the Arctic sea ice cover east of Svalbard. Adv. Meteor., 2012, 201818, doi:10.1155/2012/201818.

Jackson, J. M., E. C. Carmack, F. A. McLaughlin, S. E. Allen, and R. G. Ingram, 2010: Identification, characterization, and change of the near-surface temperature maximum in the Canada Basin, 1993-2008. J. Geophys. Res., 115, C05021, doi:10.1029/2009JC005265.

—, W. J. Williams, and E. C. Carmack, 2012: Winter sea-ice melt in the Canada Basin, Arctic
Ocean. Geophys. Res. Lett., 39, L03603, doi:10.1029 /2011GL050219.

Jakobsson, M., and Coauthors, 2012: The International Bathymetric Chart of the Arctic Ocean (IBCAO) Version 3.0. Geophys. Res. Lett., 39, L12609, doi:10.1029 /2012GL052219.

Jeffries, M. O., J. E. Overland, and D. K. Perovich, 2013: The Arctic shifts to a new normal. Phys. Today, 66, 35-40, doi:10.1063/PT.3.2147.

Kadko, D., R. S. Pickart, and J. Mathis, 2008: Age characteristics of a shelf-break eddy in the western Arctic and implications for shelf-basin exchange. J. Geophys. Res., 113, C02018, doi:10.1029/2007JC004429.

Katsman, C. A., M. A. Spall, and R. S. Pickart, 2004: Boundary current eddies and their role in the restratification of the Labrador Sea. J. Phys. Oceanogr., 34, 1967-1983, doi:10.1175/1520-0485(2004)034<1967: BCEATR $>2.0 . \mathrm{CO} ; 2$.

Kay, J. E., and T. L'Ecuyer, 2013: Observational constraints on Arctic Ocean clouds and radiative fluxes during the early 21 st century. J. Geophys. Res. Atmos., 118, 7219-7236, doi:10.1002/jgrd.50489.

Kelley, D. E., H. J. S. Fernando, A. E. Gargett, J. Tanny, and E. Ozsoy, 2003: The diffusive regime of doublediffusive convection. Prog. Oceanogr., 56, 461-481, doi:10.1016/S0079-6611(03)00026-0.

Kovacs, A., and M. Mellor, 1974: Sea ice morphology and ice as a geologic agent in the southern Beaufort Sea. The Coast and Shelf of the Beaufort Sea, J. C. Reed and J. E. Sater, Eds., Arctic Institute of North America, 113-161.

Kowalik, Z., and A. Y. Proshutinsky, 1994: The Arctic Ocean tides. The Polar Oceans and Their Role in Shaping the Global Environment, Geophys. Monogr., Vol. 85, Amer. Geophys. Union, 137-158.

Krishfield, R., J. Toole, A. Proshutinsky, and M.-L. Timmermans, 2008: Automated ice-tethered profilers for seawater observations under pack ice in all seasons. J. Atmos. Oceanic Technol., 25, 2091-2095, doi:10.1175/2008JTECHO587.1.

—, A. Proshutinsky, K. Tateyama, W. J. Williams, E. C. Carmack, F. A. McLaughlin, and M.-L. Timmermans, 2014: Deterioration of perennial sea ice in the Beaufort Gyre from 2003 to 2012 and its impact on the oceanic freshwater cycle. J. Geophys. Res. Oceans, 119, 1271-1305, doi:10.1002/2013JC008999.

Kulikov, E. A., A. B. Rabinovich, and E. C. Carmack, 2004: Barotropic and baroclinic tidal currents on the Mackenzie shelf break in the southeastern Beaufort Sea. J. Geophys. Res., 109, C05020, doi:10 .1029/2003JC001986.

,$- \ldots$, and ——, 2010: Variability of baroclinic tidal currents on the Mackenzie Shelf, the 
southeastern Beaufort Sea. Cont. Shelf Res., 30, 656-667, doi:10.1016/j.csr.2009.11.006.

Kuzmina, N., B. Rudels, V. Zhurbas, and T. Stipa, 2011: On the structure and dynamical features of intrusive layering in the Eurasian Basin in the Arctic Ocean. J. Geophys. Res., 116, C00D11, doi:10.1029/2010JC006920.

Kwok, R., 2009: Outflow of Arctic Ocean sea ice into the Greenland and Barents Seas: 1979-2007. J. Climate, 22, 2438-2457, doi:10.1175/2008JCLI2819.1.

— , and D. A. Rothrock, 1999: Variability of Fram Strait flux and North Atlantic Oscillation. J. Geophys. Res., 104, 5177-5189, doi:10.1029/1998JC900103.

— ness from submarine and ICESat records: 1958 2008. Geophys. Res. Lett., 36, L15501, doi:10.1029 /2009GL039035.

— in the Beaufort Sea to the decline in Arctic multiyear sea ice coverage: 1993-2009, Geophys. Res. Lett., 37, L20501, doi:10.1029/2010GL044678.

— sea ice. Phys. Today, 64, 36-41, doi:10.1063/1.3580491.

—, A. Schweiger, D. A. Rothrock, S. Pang, and C. Kottmeier, 1998: Sea ice motion from satellite passive microwave data assessed with ERS SAR and buoy data. J. Geophys. Res., 103, 8191-8214, doi:10.1029 /97JC03334.

—, G. F. Cunningham, M. Wensnahan, I. Rigor, H. J. Zwally, and D. Yi, 2009: Thinning and volume loss of Arctic sea ice: 2003-2008. J. Geophys. Res., 114, C07005, doi:10.1029/2009JC005312.

_-, G. Spreen, and S. Pang, 2013: Arctic sea ice circulation and drift speed: Decadal trends and ocean currents. J. Geophys. Res. Oceans, 118, 2408-2425, doi:10.1002/jgrc.20191.

Langseth, M. G., A. H. Lachenbruch, and B. V. Marshall, 1990: Geothermal observations in the Arctic region. The Arctic Ocean Region, L. A. Grantz, L. Johnson, and J. F. Sweeney, Eds., The Geology of North America, Geological Society of America, 133-151.

Lankhorst, M., 2006: A self-contained identification scheme for eddies in drifter and float trajectories. J. Atmos. Oceanic Technol., 23, 1583-1592, doi:10.1175 /JTECH1931.1.

Laxon, S. W., and Coauthors, 2013: CryoSat-2 estimates of Arctic sea ice thickness and volume. Geophys. Res. Lett., 40, 732-737, doi:10.1002/grl.50193.

Lee, S. H., and Coauthors, 2011: Holes in progressively thinning Arctic sea ice lead to new ice algae habitat. Oceanography, 24, 302-0308, doi:10.5670 /oceanog.2011.81.
Lemke, P., and T. O. Manley, 1984: The seasonal variation of the mixed layer and the pycnocline under polar sea ice. J. Geophys. Res., 89, 6494-6504, doi:10.1029/JC089iC04p06494.

Lenn, Y.-D., and Coauthors, 2009: Vertical mixing at intermediate depths in the Arctic boundary current. Geophys. Res. Lett., 36, L05601, doi:10.1029 /2008GL036792.

Levine, M. D., C. A. Paulson, and J. H. Morison, 1985: Internal waves in the Arctic Ocean: Comparison with lower-latitude observations. J. Phys. Oceanogr., 15, 800-809, doi:10.1175/1520-0485(1985)015<0800: IWITAO $>2.0 . \mathrm{CO} ; 2$.

Lien, V. S., and A. G. Trofimov, 2013: Formation of Barents Sea Branch Water in the north-eastern Barents Sea. Polar Res., 32, 18905, doi:10.3402 /polar.v32i0.18905.

—, F. B. Vikebø, and Ø. Skagseth, 2013: One mechanism contributing to co-variability of the Atlantic inflow branches to the Arctic. Nat. Commun., 4, 1488, doi:10.1038/ncomms2505.

Light, B., T. C. Grenfell, and D. K. Perovich, 2008: Transmission and absorption of solar radiation by Arctic sea ice during the melt season. J. Geophys. Res., 113, C03023, doi:10.1029/2006JC003977.

Lindsay, R. W., 1998: Temporal variability of the energy balance of thick Arctic pack ice. J. Climate, 11, 313-333, doi:10.1175/1520-0442(1998)011<0313: TVOTEB $>2.0 . C O ; 2$.

Liu, J., J. A. Curry, H. Wang, M. Song, and R. M. Horton, 2012: Impact of declining Arctic sea ice on winter snowfall. Proc. Natl. Acad. Sci. USA, 109, 4074-4079, doi:10.1073/pnas.1114910109.

Lukovich, J. V., and D. G. Barber, 2006: Atmospheric controls on sea ice motion in the southern Beaufort Sea. J. Geophys. Res., 111, D18103, doi:10.1029/2005JD006408.

Lyon, W., 1963: The submarine and the Arctic Ocean. Polar Rec., 11, 699-705, doi:10.1017 /S0032247400055959.

Manabe, S., and R. J. Stouffer, 1980: Sensitivity of a global climate model to an increase of $\mathrm{CO}_{2}$ concentration in the atmosphere. J. Geophys. Res., 85, 5529-5554, doi:10.1029/JC085iC10p05529.

Manley, T. O., 1987: Effects of sub-ice mesoscale features within the marginal ice zone of Fram Strait. J. Geophys. Res., 92, 3944-3960, doi:10.1029 /JC092iC04p03944.

- , and K. Hunkins, 1985: Mesoscale eddies of the Arctic Ocean. J. Geophys. Res., 90, 4911-4930, doi:10.1029/JC090iC03p04911.

Markus, T., J. C. Stroeve, and J. Miller, 2009: Recent changes in Arctic sea ice melt onset, freezeup, and 
melt season length. J. Geophys. Res., 114, C12024, doi:10.1029/2009JC005436.

Maykut, G. A., and N. Untersteiner, 1971: Some results from a time dependent thermodynamic model of sea ice. J. Geophys. Res., 76, 1550-1575, doi:10.1029 /JC076i006p01550.

— Arctic mixed layer. J. Geophys. Res., 100, $24691-$ 24702, doi:10.1029/95JC02554.

McLaughlin, F. A., E. C. Carmack, R. W. Macdonald, and J. K. B. Bishop, 1996: Physical and geochemical properties across the Atlantic/Pacific water mass front in the southern Canadian Basin. J. Geophys. Res., 101, 1183-1197, doi:10.1029/95JC02634.

$-, \ldots,-$, H. Melling, J. H. Swift, P. A. Wheeler, B. F. Sherr, and E. B. Sherr, 2004: On the juxtaposition of Atlantic and Pacific-origin waters in the Canada Basin, 1997-1998. Deep-Sea Res. I, 51, 107-128, doi:10.1016/j.dsr.2003.09.010.

— - _ W. J. Williams, S. Zimmerman, K. Shimada, and M. Itoh, 2009: Joint effects of boundary currents and thermohaline intrusions on the warming of Atlantic water in the Canada Basin, 1993-2007. J. Geophys. Res., 114, C00A12, doi:10.1029/2008JC005001.

McPhee, M. G., 2008: Air-Ice-Ocean Interaction: Turbulent Ocean Boundary Layer Exchange Processes. Springer, 192 pp., doi:10.1007/978-0-387 $-78335-2$.

—, T. Kikuchi, J. H. Morison, and T. P. Stanton, 2003: Ocean-to-ice heat flux at the North Pole environmental observatory. Geophys. Res. Lett., 30, 2274, doi:10.1029/2003GL018580.

Melling, H., R. A. Lake, D. R. Topham, and D. B. Fissel, 1984: Ocean thermal structure in the western Canadian Arctic. Cont. Shelf Res., 3, 233-258, doi:10.1016/0278-4343(84)90010-4.

— , P. H. Johnson, and D. A. Riedel, 1995: Measurements of the underside of sea-ice topography by moored sub-sea sonar. J. Atmos. Oceanic Technol., 12, 589-602, doi:10.1175/1520-0426(1995)012<0589:MO TUTO $>2.0 . C O ; 2$.

—, D. A. Riedel, and Z. Gedalof, 2005: Trends in the draft and extent of seasonal pack ice, Canadian Beaufort Sea. Geophys. Res. Lett., 32, L24501, doi:10.1029/2005GL024483.

Mori, M., M. Watanabe, H. Shiogama, J. Inoue, and M. Kimoto, 2014: Robust Arctic sea-ice influence on the frequent Eurasian cold winters in past decades. Nat. Geosci., 7, 869-873, doi:10.1038/ngeo2277.

Morison, J. H., C. E. Long, and M. D. Levine, 1985: Internal wave dissipation under sea ice. J. Geophys. Res., 90, 11 959-11966, doi:10.1029/JC090iC06p11959.
Munk, W., and C. Wunsch, 1998: Abyssal recipes II: Energetics of tidal and wind mixing. Deep-Sea Res. I, 45, 1977-2010, doi:10.1016/S0967-0637(98) 00070-3.

Nghiem, S. V., I. G. Rigor, D. K. Perovich, P. ClementeColón, J. Weatherly, and G. Neuman, 2007: Rapid reduction of Arctic perennial sea ice. Geophys. Res. Lett., 34, L19504, doi:10.1029/2007GL031138.

Nguyen, A. T., D. Menemenlis, and R. Kwok, 2011: Arctic ice-ocean simulation with optimized model parameters: Approach and assessment. J. Geophys. Res., 116, C04025, doi:10.1029/2010JC006573.

—, R. Kwok, and D. Menemenlis, 2012: Source and pathway of the western Arctic upper halocline in a data-constrained coupled ocean and sea ice model. J. Phys. Oceanogr., 42, 802-823, doi:10.1175 /JPO-D-11-040.1.

Nikolopoulos, A., R. S. Pickart, P. S. Fratantoni, K. Shimada, D. J. Torres, and E. P. Jones, 2009: The western Arctic boundary current at $152^{\circ} \mathrm{W}$ : Structure, variability, and transport. Deep-Sea Res. II, 56, 1164-1181, doi:10.1016/j.dsr2.2008 .10 .014 .

Nudds, S. H., and J. A. Shore, 2011: Simulated eddy induced vertical velocities in a Gulf of Alaska model. Deep-Sea Res. I, 58, 1060-1068, doi:10.1016/j .dsr.2011.08.010.

Onarheim, I. H., L. H. Smedsrud, R. Ingvaldsen, and F. Nilsen, 2014: Loss of sea ice during winter north of Svalbard. Tellus, 66, 23933, doi:10.3402/tellusa .v66.23933.

Overland, J.E., and M. Wang, 2013: When will the Arctic be nearly ice free? Geophys. Res. Lett., 40, 2097-2101, doi:10 $.1002 / g r l .50316$.

Padman, L., 1994: Momentum fluxes through sheared oceanic thermohaline steps. J. Geophys. Res., 99, 22 491-22 499, doi:10.1029/94JC01741.

_ 1995: Small-scale physical processes in the Arctic Ocean. Arctic Oceanography: Marginal Ice Zones and Continental Shelves, W. O. Smith and J. M. Grebmeier, Eds., Antarctic Research Series, Vol. 49, Amer. Geophys. Union, 97-129.

— through the Beaufort Sea thermohaline staircase. J. Geophys. Res., 92, 10 799-10 806, doi:10.1029 /JC092iC10p10799.

—, and — 1991: Turbulent mixing near the Yermak Plateau during the Coordinated Eastern Arctic Experiment. J. Geophys. Res., 96, 4769-4782, doi:10.1029/90JC02260.

— , and S. Erofeeva, 2004: A barotropic inverse tidal model for the Arctic Ocean. Geophys. Res. Lett., 31, L02303, doi:10.1029/2003GL019003. 
- A. J. Plueddemann, R. D. Muench, and R. Pinkel, 1992: Diurnal tides near the Yermak Plateau. J. Geophys. Res., 97, 12639-12652, doi:10.1029/92JC01097.

Parkinson, C. L., and D. J. Cavalieri, 2008: Arctic sea ice variability and trends, 1979-2006. J. Geophys. Res., 113, C07003, doi:10.1029/2007JC004564.

Peralta-Ferriz, C., and R. A. Woodgate, 2015: Seasonal and interannual variability of pan-Arctic surface mixed layer properties from 1979 to 2012 from hydrographic data, and the dominance of stratification for multiyear mixed layer depth shoaling. Prog. Oceanogr., 134, 19-53, doi:10.1016/j .pocean.2014.12.005.

Perovich, D. K., and C. Polashenski, 2012: Albedo evolution of seasonal Arctic sea ice. Geophys. Res. Lett., 39, L08501, doi:10.1029/2012GL051432.

— , T. C. Grenfell, B. Light, and P. V. Hobbs, 2002: Seasonal evolution of the albedo of multiyear Arctic sea ice. J. Geophys. Res., 107, 8044, doi:10.1029 /2000JC000438.

_ , B. Light, H. Eicken, K. F. Jones, K. Runciman, and S. V. Nghiem, 2007: Increasing solar heating of the Arctic Ocean and adjacent seas, 19792005: Attribution and role in the ice-albedo feedback. Geophys. Res. Lett., 34, L19505, doi:10.1029 /2007GL031480.

_ J. A. Richter-Menge, K. F. Jones, and B. Light, 2008: Sunlight, water, and ice: Extreme Arctic sea ice melt during the summer of 2007. Geophys. Res. Lett., 35, L11501, doi:10.1029/2008GL034007.

_- and Coauthors, 2011: Arctic sea ice melt in 2008 and the role of solar heating. Ann. Glaciol., 52, 355-359, doi:10.3189/172756411795931714.

—, S. Gerland, S. Hendricks, W. Meier, M. Nikolaus, and M. Tschudi, 2014a: Sea ice. Arctic report card. [Available online at www.arctic.noaa.gov/reportcard /sea_ice.html.]

- , J. A. Richter-Menge, C. M. Polashenski, B. C. Elder, T. Arbetter, and O. Brennick, 2014b: Sea ice mass balance observations from the North Pole Environmental Observatory. Geophys. Res. Lett., 41, 2019-2025, doi:10.1002/2014GL059356.

Persson, P. O. G., 2012: Onset and end of the summer melt season over sea ice: Thermal structure and surface energy perspective from SHEBA. Climate Dyn., 39, 1349-1371, doi:10.1007/s00382-011-1196-9.

— , C. W. Fairall, E. L Andreas, P. S. Guest, and D. K. Perovich, 2002: Measurements near the Atmospheric Surface Flux Group tower at SHEBA: Near-surface conditions and surface energy budget. J. Geophys. Res., 107, 8045, doi:10.1029/2000JC000705.

Peterson, A. K., and I. Fer, 2014: Dissipation measurements using temperature microstructure from an underwater glider. Methods Oceanogr., 10, 44-69, doi:10.1016/j.mio.2014.05.002.

Peterson, B. J., R. M. Holmes, J. W. McClelland, C. J. Vosmarty, R. B. Lammers, A. I. Shiklomanov, I. A. Shiklomanov, and S. Rahmstorf, 2002: Increasing river discharge to the Arctic Ocean. Science, 298, 2171-2173, doi:10.1126/science.1077445.

Pickart, R. S., 2004: Shelfbreak circulation in the Alaskan Beaufort Sea: Mean structure and variability. J. Geophys. Res., 109, C04024, doi:10.1029 /2003JC001912.

— T. J. Weingartner, L. J. Pratt, S. Zimmermann, and D. J. Torres, 2005: Flow of winter-transformed Pacific water into the Western Arctic. Deep-Sea Res. II, 52, 3175-3198, doi:10.1016/j.dsr2.2005.10.009.

Pite, H., D. R. Topham, and B. J. von Hardenberg, 1995: Laboratory measurements on the drag force of a family of two-dimensional ice keel models in a two-layer flow. J. Phys. Oceanogr., 25, 3008-3031, doi:10.1175/1520-0485(1995)025<3008:LMOTDF $>2.0 . \mathrm{CO} ; 2$.

Plueddemann, A. J., 1992: Internal wave observations from the Arctic environmental drifting buoy. J. Geophys. Res., 97, 12 619-12 638, doi:10.1029 192JC01098.

— based spectra mean estimator in the presence of band-limited noise. J. Atmos. Oceanic Technol., 8, 172-178, doi:10.1175/1520-0426(1991)008<0172 :BOTCBS $>2.0 . \mathrm{CO} ; 2$.

Pnyushkov, A. V., and I. V. Polyakov, 2012: Observations of tidally induced currents over the continental slope of the Laptev Sea, Arctic Ocean. J. Phys. Oceanogr., 42, 78-94, doi:10.1175/JPO-D-11-064.1.

,,-- V. Ivanov, Y. Aksenov, A. Coward, M. Janout, and B. Rabe, 2015: Structure and variability of the boundary current in the Eurasian Basin of the Arctic Ocean. Deep-Sea Res. I, 101, 80-97, doi:10.1016/j .dsr.2015.03.001.

Polyakov, I. V., A. V. Pnyushkov, R. Rember, V. V. Ivanov, Y.-D. Lenn, L. Padman, and E. C. Carmack, 2012a: Mooring-based observations of the doublediffusive staircases over the Laptev Sea slope. J. Phys. Oceanogr., 42, 95-109, doi:10.1175/2011JPO4606.1.

- - _, and L. A. Timokhov, 2012b: Warming of the intermediate Atlantic Water of the Arctic Ocean in the 2000s. J. Climate, 25, 8362-8370, doi:10.1175 /JCLI-D-12-00266.1.

,,-- R. Rember, L. Padman, E. C. Carmack, and J. M. Jackson, 2013: Winter convection transports Atlantic water heat to the surface layer in the eastern Arctic Ocean. J. Phys. Oceanogr., 43, 2142-2155, doi:10.1175/JPO-D-12-0169.1. 
Porter, G. H., and M. Rattray, 1964: The influence of variable depth on steady zonal barotropic flow. Dtsch. Hydrogr. Z., 17, 164-174, doi:10.1007/BF02224975.

Proshutinsky, A., and Coauthors, 2009: Beaufort Gyre freshwater reservoir: State and variability from observations. J. Geophys. Res., 114, C00A10, doi:10.1029/2008JC005104.

Radionov, V. F., N. N. Bryazgin, and E. I. Alexandrov, 1997: The snow cover of the Arctic basin. University of Washington Applied Physics Laboratory Tech. Rep. APL-UW-TR 9701, 95 pp.

Rainville, L., and P. Winsor, 2008: Mixing across the Arctic Ocean: Microstructure observations during the Beringia 2005 Expedition. Geophys. Res. Lett., 35, L08606, doi:10.1029/2008GL033532.

— internal wave generation in the seasonally ice-free Arctic. Geophys. Res. Lett., 36, L23604, doi:10.1029 /2009GL041291.

Rampal, P., J. Weiss, and D. Marsan, 2009: Positive trend in the mean speed and deformation rate of Arctic sea ice, 1979-2007. J. Geophys. Res., 114, C05013, doi:10.1029 /2008JC005066.

Rigor, I. G., and J. M. Wallace, 2004: Variations in the age of Arctic sea-ice and summer sea-ice extent. Geophys. Res. Lett., 31, L09401, doi:10.1029/2004GL019492.

—, R. L. Colony, and S. Martin, 2000: Variations in surface air temperature observations in the Arctic, 1979-1997. J. Climate, 13, 896-914, doi:10.1175 /1520-0442(2000)013<0896:VISATO>2.0.CO;2.

Rippeth, T. P., B. J. Lincoln, Y. D. Lenn, J. M. Green, A. Sundfjord, and S. Bacon, 2015: Tide-mediated warming of Arctic halocline by Atlantic heat fluxes over rough topography. Nature Geosci., 8, 191-194, doi:10.1038/ngeo2350.

Robertson, R. A., L. Padman, and M. D. Levine, 1995: Fine structure, microstructure, and vertical mixing processes in the western Weddell Sea. J. Geophys. Res., 100, 18 517-18 535, doi:10.1029/95JC01742.

Rothrock, D. A., D. B. Percival, and M. Wensnahan, 2008: The decline in arctic sea-ice thickness: Separating the spatial, annual, and interannual variability in a quarter century of submarine data. J. Geophys. Res., 113, C05003, doi:10.1029/2007JC004252.

Rudels, B., E. P. Jones, L. G. Anderson, and G. Kattner, 1994: On the intermediate depth waters of the Arctic Ocean. The Polar Oceans and Their Role in Shaping the Global Environment: The Nansen Centennial Volume, Geophys. Monogr., Vol. 85, Amer. Geophys. Union, 33-46.

,- H. J. Friedrich, and D. Quadfasel, 1999: The Arctic circumpolar boundary current. Deep-Sea Res. II, 46, 1023-1062, doi:10.1016/S0967-0645(99)00015-6.
-, N. Kuzmina, U. Schauer, T. Stipa, and V. Zhurbas, 2009: Double-diffusive convection and interleaving in the Arctic Ocean-Distribution and importance. Geophysica, 45, 199-213.

Schauer, U., and A. Beszczynska-Möller, 2009: Problems with estimating oceanic heat transport-Conceptual remarks for the case of Fram Strait in the Arctic Ocean. Ocean Sci. Discuss., 6, 1007-1029, doi:10.5194 losd-6-1007-2009.

— , and Coauthors, 2002: Confluence and redistribution of Atlantic water in the Nansen, Amundsen and Makarov basins. Ann. Geophys., 20, 257-273, doi:10 .5194/angeo-20-257-2002.

—, E. Fahrbach, S. Osterhus, and G. Rohardt, 2004: Arctic warming through the Fram Strait: Oceanic heat transport from 3 years of measurements. J. Geophys. Res., 109, C06026, doi:10.1029/2003JC001823.

— - A. Beszczynska-Möller, W. Walczowski, E. Fahrbach, J. Piechura, and E. Hansen, 2008: Variation of flow through the Fram Strait to the Arctic Ocean between 1997 and 2006. Arctic-Subarctic Ocean Fluxes: Defining the Role of the Northern Seas in Climate, B. Dickson, J. Meincke, and P. Rhines, Eds., Springer, 65-85.

Schweiger, A., R. Lindsay, J. Zhang, M. Steele, H. Stern, and R. Kwok, 2011: Uncertainty in modeled Arctic sea ice volume. J. Geophys. Res., 116, C00D06, doi:10.1029/2011JC007084.

Screen, J. A., and I. Simmonds, 2013: Exploring links between Arctic amplification and mid-latitude weather. Geophys. Res. Lett., 40, 959-964, doi:10.1002 /grl.50174.

Serreze, M. C., and R. G. Barry, 2011: Processes and impacts of Arctic amplification: A research synthesis. Global Planet. Change, 77, 85-96, doi:10.1016/j .gloplacha.2011.03.004.

— M. M. Holland, and J. Stroeve, 2007: Perspectives on the Arctic's shrinking sea-ice cover. Science, 315, 1533-1536, doi:10.1126/science.1139426.

—, A. P. Barrett, J. C. Stroeve, D. N. Knidig, and M. M. Holland, 2009: The emergence of surface-based Arctic amplification. Cryosphere, 3, 11-19, doi:10.5194 /tc-3-11-2009.

Shaw, W. J., and T. P. Stanton, 2014: Vertical diffusivity of the western Arctic Ocean halocline. J. Geophys. Res. Oceans, 119, 5017-5038, doi:10.1002 /2013JC009598.

- — - M. G. McPhee, J. H. Morison, and D. G. Martinson, 2009: Role of the upper ocean in the energy budget of Arctic sea ice during SHEBA. J. Geophys. Res., 114, C06012, doi:10.1029/2008JC004991.

Shimada, K., M. Itoh, S. Nishino, F. A. McLaughlin, E. C. Carmack, and A. Proshutinsky, 2005: Halocline 
structure in the Canada Basin of the Arctic Ocean. Geophys. Res. Lett., 32, L03605, doi:10.1029 /2004GL021358.

—, T. Kamoshida, M. Itoh, S. Nishino, E. Carmack, F. McLaughlin, S. Zimmermann, and A. Proshutinsky, 2006: Pacific Ocean inflow: Influence on catastrophic reduction of sea ice cover in the Arctic Ocean. Geophys. Res. Lett., 33, L08605, doi:10.1029/2005GL025624.

Sirevaag, A., and I. Fer, 2009: Early spring oceanic heat fluxes and mixing observed from drift stations north of Svalbard. J. Phys. Oceanogr., 39, 3049-3069, doi:10.1175/2009JPO4172.1.

— and - 2012: Vertical heat transfer in the Arctic Ocean: The role of double-diffusive mixing. $J$. Geophys. Res., 117, C07010, doi:10.1029/2012JC007910.

Smith, D. C., J. H. Morison, J. A. Johannessen, and N. Untersteiner, 1984: Topographic generation of an eddy at the edge of the East Greenland Current. J. Geophys. Res., 89, 8205-8208, doi:10.1029 /JC089iC05p08205.

Smith, K. S., and R. Ferrari, 2009: The production and dissipation of compensated thermohaline variance by mesoscale stirring. J. Phys. Oceanogr., 39, 2477-2501.

Spall, M. A., 2013: On the circulation of Atlantic Water in the Arctic Ocean. J. Phys. Oceanogr., 43, 2352-2371, doi:10.1175/JPO-D-13-079.1.

- , R. S. Pickart, P. S. Fratantoni, and A. J. Plueddemann, 2008: Western Arctic shelfbreak eddies: Formation and transport. J. Phys. Oceanogr., 38, 1644-1668, doi:10.1175/2007JPO3829.1.

Spielhagen, R. F., and Coauthors, 2011: Enhanced modern heat transfer to the Arctic by warm Atlantic water. Science, 331, 450-453, doi:10.1126/science .1197397.

Spreen, G., R. Kwok, and D. Menemenlis, 2011: Trends in Arctic sea ice drift and role of wind forcing: 1992-2009. Geophys. Res. Lett., 38, L19501, doi:10.1029/2011GL048970.

Stammerjohn, S., R. Massom, D. Rind, and D. Martinson, 2012: Regions of rapid sea ice change: An inter-hemispheric seasonal comparison. Geophys. Res. Lett., 39, L06501, doi:10.1029/2012GL050874.

Steele, M., J. Morison, W. Ermold, I. Rigor, M. Ortmeyer, and K. Shimada, 2004: Circulation of summer Pacific halocline water in the Arctic Ocean. J. Geophys. Res., 109, C02027, doi:10.1029/2003JC002009.

_ , W. Ermold, and J. Zhang, 2011: Modeling the formation and fate of the near-surface temperature maximum in the Canadian Basin of the Arctic Ocean. J. Geophys. Res., 116, C11015, doi:10.1029 /2010JC006803.
Straneo, F., and Coauthors, 2013: Challenges to understand the dynamic response of Greenland's marine terminating glaciers to oceanic and atmospheric forcing. Bull. Amer. Meteor. Soc., 94, 1131-1144, doi:10.1175/BAMS-D-12-00100.1.

Stroeve, J. C., M. C. Serreze, M. M. Holland, J. E. Kay, J. Masklanik, and A. P. Barrett, 2012: The Arctic's rapidly shrinking sea ice cover: A research synthesis. Climatic Change, 110, 1005-1027, doi:10.1007 /s10584-011-0101-1.

Sturm, M., J. Holmgren, and D. Perovich, 2002: Winter snow cover on the sea ice of the Arctic Ocean at the Surface Heat Budget of the Arctic Ocean (SHEBA): Temporal evolution and spatial variability. $J$. Geophys. Res., 107, 8047, doi:10.1029/2000JC000400.

Thomas, L. N., A. Tandon, and A. Mahadevan, 2008: Submesoscale processes and dynamics. Ocean Modeling in an Eddying Regime, Geophys. Monogr., Vol. 177, Amer. Geophys. Union, 17-38.

Thorndike, A. S., and R. Colony, 1982: Sea ice motion in response to geostrophic winds. J. Geophys. Res., 87, 5845-5852, doi:10.1029/JC087iC08p05845.

Tietsche, S., D. Notz, J. H. Jungclaus, and J. Marotzke, 2011: Recovery mechanisms of Arctic summer sea ice. Geophys. Res. Lett., 38, L02707, doi:10.1029 /2010GL045698.

Timmermans, M.-L., and P. Winsor, 2013: Scales of horizontal density structure in the Chukchi Sea surface layer. Cont. Shelf Res., 52, 39-45, doi:10.1016/j .csr.2012.10.015.

—, J. Toole, R. Krishfield, and P. Winsor, 2008a: IceTethered Profiler observations of the double-diffusive staircase in the Canada Basin thermocline. J. Geophys. Res., 113, C00A02, doi:10.1029/2008JC004829.

$\longrightarrow,-$, A. Proshutinsky, R. Krishfield, and A. Plueddemann, 2008b: Eddies in the Canada Basin, Arctic Ocean, observed from ice-tethered profilers. J. Phys. Oceanogr., 38, 133-145, doi:10.1175 /2007JPO3782.1.

—, S. Cole, and J. Toole, 2012: Horizontal density structure and restratification of the Arctic Ocean surface layer. J. Phys. Oceanogr., 42, 659-668, doi:10.1175 /JPO-D-11-0125.1.

— , and Coauthors, 2014: Mechanisms of Pacific Summer Water variability in the Arctic's Central Canada Basin. J. Geophys. Res. Oceans, 119, 75237548, doi:10.1002/2014JC010273.

Toole, J. M., M.-L. Timmermans, D. K. Perovich, R. A. Krishfield, A. Proshutinsky, and J. A. Richter-Menge, 2010: Influences of the ocean surface mixed layer and thermohaline stratification on Arctic Sea ice in the central Canada Basin. J. Geophys. Res., 115, C10018, doi:10.1029/2009JC005660. 
—, R. A. Krishfield, M.-L. Timmermans, and A. Proshutinsky, 2011: The Ice-Tethered Profiler: Argo of the Arctic. Oceanography, 24, 126-135, doi:10.5670/oceanog.2011.64.

Tucker, W. B., III, W. F. Weeks, and M. Frank, 1979: Sea ice ridging over the Alaskan continental shelf. J. Geophys. Res., 84, 4885-4897, doi:10.1029/JC084iC08p04885.

Turner, J. S., 1973: Buoyancy Effects in Fluids. Cambridge University Press, 368 pp.

Untersteiner, N., 1988: On the ice and heat balance in Fram Strait. J. Geophys. Res., 93, 527-531, doi:10.1029 /JC093iC01p00527.

Vaughan, D. G., and Coauthors, 2013: Observations: Cryosphere. Climate Change 2013: The Physical Science Basis, T. F. Stocker, Eds., Cambridge University Press, 317-382.

Vihma, T., and Coauthors, 2014: Advances in understanding and parameterization of small-scale physical processes in the marine Arctic climate system: A review. Atmos. Chem. Phys., 14, 94039450, doi:10.5194/acp-14-9403-2014.

Wadhams, P., and R. J. Horne, 1980: An analysis of ice profiles obtained by submarine sonar in the Beaufort Sea. J. Glaciol., 25, 401-424.

Walsh, D., and E. Carmack, 2003: The nested structure of Arctic thermohaline intrusions. Ocean Modell., 5, 267-289, doi:10.1016/S1463-5003(02)00056-2.

Warren, B. A., 1969: Divergence of isobaths as a cause of current branching. Deep-Sea Res., 6, 339-355.

Warren, S., I. Rigor, N. Untersteiner, V. F. Radionov, N. N. Bryazgin, Y. I. Aleksandrov, and R. Colony, 1999: Snow depth on Arctic sea ice. J. Climate, 12, 1814-1829, doi:10.1175/1520-0442(1999)012<1814: SDOASI>2.0.CO;2.

Wassmann, P., and T. Lenton, 2012: Arctic tipping points in the Earth System perspective. Ambio, 41, 1-9, doi:10.1007/s13280-011-0230-9.

Watanabe, E., and H. Hasumi, 2009: Pacific water transport in the western Arctic Ocean simulated by an eddy-resolving coupled sea ice-ocean model. J. Phys. Oceanogr., 39, 2194-2211, doi:10.1175/2009JPO4010.1.

Webster, M. A., I. G. Rigor, S. V. Nghiem, N. T. Kurtz, S. L. Farrell, D. K. Perovich, and M. Sturm, 2014: Interdecadal changes in snow depth on Arctic sea ice. J. Geophys. Res. Oceans, 119, 5395-5406, doi:10.1002 /2014JC009985.

Weingartner, T. J., K. Aagaard, R. A. Woodgate, S. Danielson, Y. Sasaki, and D. Cavalieri, 2005: Circulation on the north central Chukchi Sea shelf. Deep-Sea Res. II, 52, 3150-3174, doi:10.1016/j .dsr2.2005.10.015.
Whitefield, J., P. Winsor, J. McClelland, and D. Menemenlis, 2015: A new river discharge and river temperature climatology data set for the panArctic region. Ocean Modell., 88, 1-15, doi:10.1016/j .ocemod.2014.12.012.

Woodgate, R. A., K. Aagaard, R. D. Muench, J. Gunn, G. Bjork, B. Rudels, A. T. Roach, and U. Schauer, 2001: The Arctic Ocean boundary current along the Eurasian slope and the adjacent Lomonosov Ridge: Water mass properties, transports and transformations from moored instruments. Deep-Sea Res. I, 48, 1757-1792, doi:10.1016/S0967 -0637(00)00091-1.

,-- , and T. J. Weingartner, 2005: A year in the physical oceanography of the Chukchi Sea: Moored measurements from autumn 1990-1991. Deep-Sea Res. II, 52, 3116-3149, doi:10.1016/j.dsr2 .2005.10.016.

,-- , and -2006 : Interannual changes in the Bering Strait fluxes of volume, heat and freshwater between 1991 and 2004. Geophys. Res. Lett., 33, L15609, doi:10.1029/2006GL026931.

— - , J. H. Swift, W. M. Smethie Jr., and K. K. Falkner, 2007: Atlantic water circulation over the Mendeleev Ridge and Chukchi Borderland from thermohaline intrusions and water mass properties. J. Geophys. Res., 112, C02005, doi:10.1029 /2005JC003416.

_ - T. Weingartner, and R. Lindsay, 2010: The 2007 Bering Strait oceanic heat flux and anomalous Arctic sea-ice retreat. Geophys. Res. Lett., 37, L01602, doi:10.1029/2009GL041621.

,$- \ldots$, and — 2012: Observed increases in Bering Strait oceanic fluxes from the Pacific to the Arctic from 2001 to 2011 and their impacts on the Arctic Ocean water column. Geophys. Res. Lett., 39, L24603, doi:10.1029/2012GL054092.

Yamamoto-Kawai, M., F. A. McLaughlin, E. C. Carmack, S. Nishino, K. Shimada, and N. Kurita, 2009: Surface freshening of the Canada Basin, 2003-2007: River runoff versus sea ice meltwater. J. Geophys. Res., 114, C00A05, doi:10.1029/2008JC005000.

Zakharchuk, E. A., 1999: Internal waves in the Laptev Sea. Land-Ocean Systems in the Siberian Arctic, H. Kassens et al., Eds., Springer Berlin Heidelberg, 43-51.

Zhao, M., M.-L. Timmermans, S. Cole, R. Krishfield, A. Proshutinsky, and J. Toole, 2014: Characterizing the eddy field in the Arctic Ocean halocline. $J$. Geophys. Res. Oceans, 119, 8800-8817, doi:10.1002 /2014JC010488. 


\section{Radar and Atmospheric Science: A Collection of Essays in Honor of David Atlas}

Edited by Roger M. Wakimoto and Ramesh Srivastava

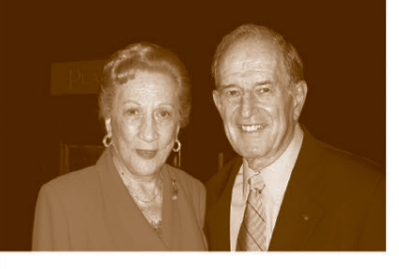

This monograph pays tribute to one of the leading scientists in meteorology, Dr. David Atlas. In addition to profiling the life and work of the acknowledged "Father of Radar Meteorology," this collection highlights many of the unique contributions he made to the understanding of the forcing and organization of convective systems, observation and modeling of atmospheric turbulence and waves, and cloud microphysical properties, among many other topics. It is hoped that this text will inspire the next generation of radar meteorologists, provide an excellent resource for scientists and educators, and serve as a historical record of the gathering of scholarly contributions honoring one of the most important meteorologists of our time.

Radar and Atmospheric Science: A Collection of Essays in Honor of David Atlas Aug 2003. Meteorological Monograph Series, Vol. 30, No. 52; 270 pp, hardbound; ISBN 1-878220-57-8; AMS code MM52.

Price $\$ 100.00$ list $/ \$ 80.00$ member

To place an order point your Web browser to www.ametsoc.org/amsbookstore

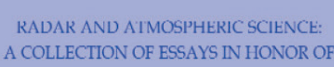

RADAR AND AIMOSPHERIC SCIENCE:

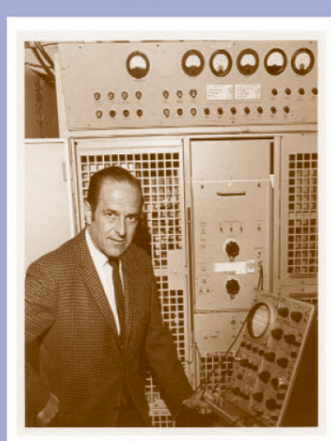

